\title{
ETIOLOGIA I KONTEKSTY POLITYKI PUBLICZNEJ PRZECIWDZIALANIA PRZEMOCY W RODZINIE W POLSCE
}

\author{
AETIOLOGY AND CONTEXTS OF PUBLIC POLICY AIMED \\ AT PREVENTING DOMESTIC VIOLENCE IN POLAND
}

\section{Piotr Zalewski*}

\begin{abstract}
Abstrakt
Autor analizuje strukturę polityki walki $\mathrm{z}$ przemocą $\mathrm{w}$ rodzinie w Polsce, z perspektywy historycznego rozwoju polityk publicznych przeciwdziałania przemocy domowej w Polsce oraz źródeł i przyczyn stojących za konkretnymi rozwiązaniami. Szczególną uwagę poświęca etiologii kształtowania się procesu rozszerzania ochrony praw człowieka z przestrzeni publicznej do sfery prywatnej konkretnych jednostek na świecie i w Europie, a także budowaniu społecznych (obywatelskich) i instytucjonalnych ram najważniejszych instytucji związanych z przeciwdziałaniem przemocy w rodzinie w Polsce. Przedstawia sposób formułowania oraz implementowania na gruncie krajowym elementów tworzących system przeciwdziałania przemocy. Posługuje się klasycz-
\end{abstract}

\begin{abstract}
The author analyses the structure of the policy aimed at preventing domestic violence in Poland from the perspective of the historical development of public policies of domestic violence prevention in Poland and the sources of and causes for particular solutions. Especially close attention is paid to the aetiology of broadening the protection guaranteed by human rights, which both in the world and Europe was extended from public space onto the private sphere of individual persons. Moreover, what is discussed is the process of building social (civil) framework of the most important institutions related to the prevention of domestic violence in Poland. The author presents the manner of establishing and implementing elements creating the system of violence prevention at the state level.
\end{abstract}

* Wydział Prawa i_Nauk Społecznych, Uniwersytet Jana Kochanowskiego w Kielcach; (p.zalewski@op.pl); iD https://orcid.org/0000-0002-0997-8561. 
nymi metodami analizy znanymi z zakresu wiedzy o politykach publicznych.

Słowa kluczowe: przemoc $\mathrm{w}$ rodzinie, przeciwdziałanie przemocy, polityki publiczne
He utilises classical methods of analysis, known in the field of public policies study.

Key words: domestic violence, prevention of violence, public policies

\section{Wprowadzenie}

Proces rozwoju ochrony praw człowiek, jaki dokonał się na świecie w drugiej połowie XX wieku, pozwolił na upublicznienie i wprowadzenie do agendy dyskursu politycznego zjawiska przemocy domowej. Złożoność przyczyn determinujących przemoc domową, skutki jednostkowe i społeczne (występujące bezpośrednio po, jak i te oddalone w czasie), jakie towarzyszą wszelkim aktom przemocy $\mathrm{w}$ relacjach rodzinnych, sprawiają, że jest to jeden z najpoważniejszych problemów społecznych współczesnych państw (Jaszczak-Kuźmińska, Michalska, (red.), 2010). Pojęcie przemocy domowej pojawia się w kontekście uwarunkowań kulturowych, zdrowia publicznego i zjawisk związanych z gospodarką, ekonomią i patologiami społecznymi, takimi jak na przykład alkoholizm, narkomania, przestępczość. Zdiagnozowanie symptomów i skali tego zjawiska, a w konsekwencji udzielenie systemowej pomocy ofiarom przemocy w rodzinie wymaga interdyscyplinarnego podejścia badawczego i zintegrowanego na każdym poziomie działania międzyinstytucjonalnego'. Fenomen przemocy domowej dotyczy różnych kategorii ofiar, niesie z sobą poważne skutki w wymiarze jednostkowym i społecznym, co wyznacza wspólne obszary działania dla przedstawicieli różnych profesji, którzy swoje zadania realizują z zastosowaniem i wykorzystaniem odmiennych instrumentów i procedur. Będzie to zatem pole do działania dla pracowników socjalnych, oświaty, ochrony zdrowia, wymiaru sprawiedliwości, Policji, służby kuratorskiej, Kościołów i Wspólnot religijnych, wolontariuszy i organizacji pozarządowych. Ważnym elementem spajającym podejmowane działania jest potrzeba zaawansowanej wiedzy i umiejętności w zakresie diagnozowania i badania problemów przemocy domowej, a także tworzenia efektywnych sposobów radzenia sobie z przemocą domową na podstawie pogłębionej refleksji naukowej.

Rozszerzenie zakresu ochrony praw człowieka na sferę życia prywatnego jednostki, jakie dokonało się w ostatnich kilkunastu latach, wraz z implemen-

${ }^{1} \mathrm{Na}$ temat interdyscyplinarnego i międzyinstytucjonalnego podejścia do zjawiska przemocy domowej i jej międzynarodowego występowania zob.: Pospiszyl (1994, s. 15), Castiglia (1995, s. 271), Lamela, Iongenelen, Levendovsky (2018, s. 61), Emery (1989, s. 321), Chan, Choi, Wai, Fong, Chow, Leung, Ip (2013, s. 249), Haj-Yahia, de Zoysa (2008, s. 997). 
tacją międzynarodowych standardów i przepisów spowodowało włączenie przeciwdziałania przemocy domowej i pomocy dla ofiar do polityki publicznej wielu państw demokratycznych. W Polsce działania te przejawiały się najpierw w aktywności organizacji pozarządowych wspierających respektowanie praw kobiet i dzieci, a następnie jako instytucjonalne wzmacnianie polityki publicznej w tym zakresie dzięki wprowadzaniu specjalnego ustawodawstwa oraz realizacji sprecyzowanych programów działań przez instytucje tworzące administrację rządową i samorządową, a także organizacje pozarządowe.

Celem autora artykułu jest próba przedstawienia historycznego rozwoju polityk publicznych przeciwdziałania przemocy domowej w Polsce oraz wskazanie źródeł i przyczyn stojących za konkretnymi rozwiązaniami. Szczególna uwaga zostanie poświęcona etiologii kształtowania się procesu rozszerzania ochrony praw człowieka z przestrzeni publicznej do sfery prywatnej konkretnych jednostek na świecie i w Europie, a także budowaniu społecznych (obywatelskich) i instytucjonalnych ram najważniejszych instytucji związanych z przeciwdziałaniem przemocy w rodzinie w Polsce. Złożoność podejmowanych w pracy zagadnień sprawia, że w rozważaniach o charakterze interdyscyplinarnym wykorzystano teoretyczne ramy analizy polityki publicznej opartej na sekwencyjnym procesie tworzenia polityki publicznej, a także zastosowano metodę analizy prawno-dogmatycznej, umożliwiającą interpretację norm prawa obowiązującego. Za pomocą tej metody zostanie dokonana analiza obowiązujących aktów prawnych, a w szczególności Konstytucji Rzeczypospolitej Polskiej, ustawodawstwa, aktów wykonawczych, a także norm prawa międzynarodowego, zarówno tych o charakterze umownym (wiążącego w systemie prawa międzynarodowego publicznego), jak i tych o charakterze ,miękkiego prawa”. Użycie metody analizy systemowej umożliwi zbadanie zjawiska przemocy w rodzinie w szerszym kontekście przyczyn i skutków, jakie towarzyszą funkcjonowaniu współczesnych rodzin, co ułatwi zrozumienie tworzenia się patologii w tym obszarze. Metoda analizy historycznej pomoże w uchwyceniu ewolucji form i metod zwalczania zjawiska przemocy w rodzinie, z uwzględnieniem instrumentów prawnych zarówno o krajowym, jak i międzynarodowym charakterze. $\mathrm{Z}$ zastosowaniem metody analizy empirycznej zostanie dokonana analiza wybranych działań projektowanych $\mathrm{w}$ ramach tworzonych polityk publicznych przeciwdziałania przemocy domowej w Polsce.

Formułując założenia metodologiczne badania projektowania i implementacji polityk publicznych przeciwdziałania przemocy domowej w Polsce, celowo zrezygnowano $\mathrm{z}$ formułowania hipotez ze względu na brak przesłanek teoretycznych i empirycznych do konstruowania konkretnych i ukierunkowanych hipotez badawczych. Stosunkowo mało jest jeszcze pogłębionych badań i wiarygodnej ewaluacji polityk walki z przemocą w rodzinie w odniesieniu do kluczowych aspektów tych działań. Dostępne dane są rozproszone, brak jest jasnych i jednolitych metodologii ich analizy i prezentowania (Jelonek, Keler, Worek, 
2010, s. 50). W to miejsce urzędy publiczne przedstawiają sprawozdania i opracowania, w których dominują przetworzone dane o charakterze statystycznym (Zybała, 2012, s. 11; 2013, s. 104-106) ${ }^{2}$. Analiza opisywanego zagadnienia poprzedzona zostanie przedstawieniem charakterystyki przemocy domowej i polityk publicznych (polityki publicznej). Zgodnie z przyjętą w licznych publikacjach praktyką pojęcie przemocy domowej używane jest zamiennie z pojęciami przemocy w rodzinie, przemocy wewnatrzrodzinnej, znęcania się nad rodzina ${ }^{3}$.

\section{Zjawisko przemocy domowej}

Pojęcie przemocy, w kontekście historycznym i społecznym wydaje się zjawiskiem powszechnie zrozumiałym. Jednakże brak jest definicji absolutnej, która precyzowałaby jednoznacznie rozumienie tego zjawiska. Podobne trudności występują w definiowaniu pojęcia przemocy domowej, dlatego w artykule będę opierał się na definicji, zawartej w Ustawie o przeciwdziałaniu przemocy $\mathrm{w}$ rodzinie, gdzie przemoc w rodzinie to ,jednorazowe albo powtarzające się umyślne działanie lub zaniechanie naruszające prawa lub dobra osobiste osób najbliższych, także innych osób wspólnie zamieszkujących lub gospodarujących, w szczególności narażające te osoby na niebezpieczeństwo utraty życia, zdrowia, naruszające ich godność, nietykalność cielesną, wolność, w tym seksualną, powodujące szkody na ich zdrowiu fizycznym lub psychicznym, a także wywołujące cierpienia i krzywdy moralne u osób dotkniętych przemocą" (Ustawa z dnia 29 lipca 2005 roku). Podobną definicję można znaleźć w dokumentach Komitetu Ministrów Rady Europy nr R/85/4 w sprawie przemocy w rodzinie z 26 marca 1985 roku, w których przemoc w rodzinie opisana została jako „każde działanie lub zaniechanie podjęte w ramach rodziny przez jednego z jej członków, które godzi w życie, integralność fizyczną lub psychiczną albo w wolność innego członka tej samej rodziny lub które poważnie szkodzi rozwojowi jego osobowości” (Bryk, 2003, s. 12). O tym, że przemoc godzi w wolność osobistą jednostki, wspomina również w swojej definicji Irena Pospiszyl, twierdząc, że przemoc, to „wszelkie nieprzypadkowe akty godzące w osobistą

${ }^{2}$ Do nielicznych zaliczyć można raport Najwyższej Izby Kontroli (Przeciwdziałanie przemocy..., 2013), aczkolwiek raport nie ma charakteru ewaluacyjnego.

3 Wielość perspektyw i kontekstów badawczych sprawia, że trudności definicyjne związane z opisaniem zjawiska przemocy rozumianej szeroko oraz przemocy skierowanej przeciwko najbliższym, wynikają przede wszystkim z problemu określenia różnic między pojęciami takimi, jak przemoc, agresja, przemoc domowa, przemoc w związu partnerskim, przemoc $w$ rodzinie, przemoc matżeńska (ang. aggression, violence and criminal violence, couple violence, domestic violence, family violence, marital violence, spousal violence). 
wolność jednostki lub przyczyniające się do fizycznej, a także psychicznej szkody osoby, wykraczające poza społeczne zasady wzajemnej relacji” (Pospiszyl, 1994, s. 15).

W literaturze anglojęzycznej przemoc w rodzinie określana jest bardzo często terminami family violence i domestic violence. Termin domestic violence rozumiano do niedawna jako przemoc mężczyzny wobec kobiety, zazwyczaj żony, w domu. W ostatnim czasie pojęcie to nabrało szerszego znaczenia i używa się go także do określenia zarówno przemocy, jak i agresji oraz różnych jej przejawów, na przykład groźby użycia przemocy fizycznej, seksualnej czy emocjonalnej. Sprawcami mogą być nie tylko mąż, ale także chłopak, partner, przyjaciel oraz były mąż, były partner, syn, ojciec, brat lub inny bliski członek rodziny. Gill Hague i Ellen Malos wskazują, że przemoc może być zagrażająca życiu, systematyczna oraz długotrwała. Autorzy podkreślają również, że przemoc może być realizowana w różnych miejscach, choć dom rodzinny pozostaje jak do tej pory głównym miejscem występowania jej przejawów (Hague, Malos 1994, s. 101). W licznych opracowaniach krajowych pojęcie przemocy domowej używane jest zamiennie z pojęciem przemocy w rodzinie, przemocy wewnątrzrodzinnej, znęcania się nad rodziną.

Przemoc w rodzinie to zamierzone i wykorzystujące przewagę sił działanie skierowane przeciw członkowi rodziny, które narusza prawa i dobra osobiste, powodując cierpienie i szkody. Termin ten stosuje się także na określenia przemocy psychicznej, która może się objawiać w postaci nawracającego znęcania się słownego, szykowania, ograniczania i pozbawienia środków materialnych, finansowych i osobistych, kontrolowania kontaktów z członkami rodziny i przyjaciółmi. Przemoc w rodzinie przybiera postać różnych nadużyć, które nie są penalizowane, oraz zachowań skodyfikowanych w przepisach karnych. Różne formy i przejawy zachowań przemocowych występują zazwyczaj łącznie, $\mathrm{w}$ różnych wariantach i różnym natężeniu. W literaturze opisuje się przemoc fizyczną, psychiczną (emocjonalną), seksualną, ekonomiczną oraz przemoc poprzez zaniedbanie (izolacja społeczna), a w stosunku do dzieci ponadto wszelkie formy zaniedbań opiekuńczych i wychowawczych (Pospiszyl, 2008, s. 14). Najczęściej ofiarami przemocy są kobiety i dzieci, seniorzy, rzadziej mężczyźni. Sprawcami zachowań przemocowych najczęściej okazują się mężczyźni (głównie pod wpływem alkoholu), rzadziej kobiety. W statystykach dotyczących przemocy $\mathrm{w}$ rodzinie coraz częściej odnotowywane są przypadki przemocy dzieci w stosunku do rodziców (nie dotyczy to kategorii „seniorzy”) oraz przemoc w relacjach między rodzeństwem (Zalewski, Janułajtys, 2017, s. 243 i nast.).

Przemoc w rodzinie prowadzi do występowania wielu negatywnych skutków w wymiarze zarówno indywidualnym, jak i społecznym. Do najbardziej symptomatycznych objawów emocjonalnych, chorobowych i społecznych doświadczania przemocy domowej należą między innymi poważne obrażenia ciała, kalectwo, choroby somatyczne (np. bóle głowy, żołądka), wyuczona bezradność 
(bierne znoszenie zachowań krzywdzących), wzmożone napięcie emocjonalne, impulsywność, zaburzenia depresyjne: obniżony nastrój, emocjonalne otępienie, niska samoocena, brak chęci do działania, negatywne myślenie o sobie, świecie, przyszłości, stany lękowe, płaczliwość, próby samobójcze; zaburzenia lękowe: lęk przed podjęciem działania, przed krytyką, przed odrzuceniem; nieufność wobec otoczenia i brak umiejętności nawiązywania kontaktów społecznych; z zaburzeniami lękowymi często współwystępują zaburzenia odżywiania, depresje, uzależnienia; zaburzenia adaptacyjne w pokonywaniu codziennych trudności. Doznawana w dzieciństwie przemoc może powodować wystąpienie depresji nawet w wieku przedszkolnym i szkolnym, objawiającej się zaburzeniami emocjonalnymi, trwałym przeżywaniem smutku, przygnębienia, ale także rozdrażnieniem lub stanami lękowymi, zaburzeniami zachowania, spowolnieniem lub nadpobudliwością ruchową, społecznym wycofaniem, zaburzeniem funkcji poznawczych, ograniczeniem zainteresowan, problemami z koncentracją uwagi, obniżeniem tempa nauki, objawami somatycznymi, utratą łaknienia, zaburzeniami snu, bólami brzucha, głowy, zaburzeniami miesiączkowania. Depresje u młodzieży manifestują się zaburzeniami lękowymi, fobią społeczną, zaburzeniami obsesyjno-kompulsywnymi; znaczna część młodzieży z depresją stosuje przy tym używki, tj. alkohol i narkotyki. Problemy zdrowotne osób dorosłych doznających przewlekłej przemocy w rodzinie najczęściej objawiają się jako depresja, zaburzenia osobowości, zaburzenia lękowe, psychozy schizofreniczne, przewlekłe choroby somatyczne i uzależnienie od leków. Do konsekwencji długoterminowych należy także zespół jelita drażliwego i choroba niedokrwienna serca. Osoby doświadczające przemocy domowej lub obserwujące ją częściej stają się bardziej agresywne i wrogie w stosunku do innych ludzi, są mniej odpowiedzialne za wszystko, co w życiu robią, mają trudności w kontaktach z innymi ludźmi (są mniej komunikatywne, bardziej drażliwe, nieufne), częściej żyją w rozbitych rodzinach i nie utrzymują kontaktów z najbliższymi krewnymi, częściej ponoszą porażki zawodowe i trudniej im osiągnąć ważne życiowe cele, trudniej im założyć własną rodzinę, a jeżeli im się to uda, są to często rodziny nietrwałe (Krupka-Matuszczyk (red.), 2004).

\section{Polityka publiczna (polityki publiczne)}

W refleksji akademickiej w Polsce polityka publiczna definiowana jest jako „zracjonalizowane działania i programy publiczne, które oparte są na zgromadzonej, względnie zobiektywizowanej wiedzy i usystematyzowanym procesie projektowania i wykonywania tych działań" (Zybała, 2012, s. 22). Procesy te wynikają z założenia, że ,jeżeli w określonych warunkach podjęte zostaną ta- 
kie, a nie inne działania, to można się spodziewać zaplanowanego rezultatu" (Tkaczyński, Świstak, 2015, s. 11). Jerzy Woźnicki istotę nauki o polityce charakteryzuje w następujący sposób: „Polityka publiczna służy nadawaniu porządku zadaniom publicznym, od ich projektowania, poprzez realizowanie, aż do oceny wyników. Politykę publiczną można określić jako zbiór procesów, których realizację podejmuje administracja w ramach swej misji zaspokajania potrzeb publicznych. Oznacza to, że cele polityki publicznej wskazywane są przez szeroko pojmowane podmioty sprawujące władzę (w tym także organy władzy ustawodawczej), a konkretyzacja i wykonywanie zadań powierzane są organom administracji publicznej" (Woźnicki, 2012, s. 134).

Procesy, działania, które są podejmowane, w rozumieniu polityki publicznej, realizowane są przez ,władzę publiczną", rozumianą wąsko — jako decyzje i działania „organów rządowych”, bądź szeroko — jako udział w kształtowaniu i realizacji polityki publicznej instytucji sektora publicznego, społeczno-obywatelskiego i prywatno-rynkowego (Anioł, 2018, s. 21). Potrzeba formułowania i wdrażania polityk publicznych wynika z konieczności rozwiązywania powstających problemów społecznych i cywilizacyjnych, które swoim natężeniem przekraczają możliwości pokonania ich na poziomie jednostkowym lub lokalnym. Cechami charakterystycznymi polityki publicznej jest wielodyscyplinarne podejście; skoncentrowanie na problemach, które są podejmowane w określonych kontekstach sytuacyjnych; orientacja na rozwiązania normatywne; kompleksowy proces działań publicznych, oparty na sekwencyjnym tworzenia polityki publicznej i wdrażaniu kolejnego etapu po zakończeniu poprzedniego (Mazur, 2015, s. 8 i nast.; Sakowicz, 2016, s. 41)4.

Podejścia badawcze studiów nad politykami publicznymi obejmują szerokie ramy badawcze, a tworzące je elementy są mocno zróżnicowane (Mazur, 2015, s. 15). Dlatego też autor odwołuje się do koncepcji faz procesu politycznego opracowanego przez Harolda Lasswella. W podejściu tym polityki publiczne traktowane są jako linearny, sekwencyjny i rekursywny proces podejmowania decyzji, gdzie kolejnymi stadiami są identyfikacja problemu, określenie alternatywnych rozwiązań, implementacja najlepszego rozwiązania i ewaluacja wdrożonego rozwiązania na zidentyfikowany problem (Mazur, 2015, s. 16).

W tak zarysowanych ramach konceptualnych lokować można analizy działań publicznych $\mathrm{w}$ różnych rodzajach interwencji publicznych, $\mathrm{w}$ tym $\mathrm{w}$ kreowaniu i realizacji polityki przeciwdziałania przemocy w rodzinie. Ze względu na złożony charakter zjawiska przemocy w rodzinie realizacja polityki publicznej w tym zakresie odbywa się poprzez współzależnie podejmowane decyzje

${ }^{4}$ Model stadialny Lasswella oparty został na wyodrębnieniu siedmiu faz realizacji polityki publicznej. W kolejnych dekadach powstawały podobnie rozbudowane modele stadialne, np. pięć faz realizacji polityki publicznej w ujęciu Jamesa E. Andersona, czy też koncepcje ograniczające się do dwóch faz, tj. projektowania polityki oraz jej implementacji. Więcej zob. Mering (2018, s. 162). 
w różnych sektorach działalności państwa, polegające na potrzebie spójności w zakresie dobrej legislacji oraz efektywnej współpracy wielu interesariuszy, którzy będą podejmować skoordynowane działania edukacyjne (przełamywanie stereotypów, uprzedzeń, walka z niewiedzą, budowanie sieci wsparcia), interwencyjne, terapeutyczne, socjalne, prawne, medyczne itp. Analizując architekturę polityki walki z przemocą w rodzinie, Andrzej Zybała konkluduje, że „polityka ta, jako zespół działań i interwencji publicznych, nigdy nie będzie łatwa do formułowania, a szczególnie do wdrażania" (Zybała, 2014, s. 1). Główne problemy w realizacji polityki przeciwdziałania przemocy w rodzinie według przywoływanego badacza mogą wynikać z niskiego poziomu współpracy interesariuszy zaangażowanych $\mathrm{w}$ interwencje publiczne, niedopasowania narzędzi działania do charakteru problemu (przewaga narzędzi legislacyjnych nad perswazyjnymi i terapeutycznymi, niewłaściwa linia orzecznicza w zakresie karania za przestępstwa $\mathrm{w}$ rodzinie), brak wystarczającej infrastruktury wsparcia ofiar przemocy, ograniczone możliwości przeciwdziałania przemocy ze strony samorządowych instytucji pomocy społecznej (Zybała, 2014, s. 1).

Przyjmując za punkt odniesienia perspektywę działań publicznych zogniskowanych wokół konkretnych problemów czy kwestii do rozwiązania, identyfikowanych jako kluczowe dla poszczególnych grup lub środowisk, politykę przeciwdziałania przemocy w rodzinie traktować można jako jedną ze szczegółowych polityk społecznych, czyli subdyscyplin polityki społecznej (Golinowska, 1994, s. 116). Polityka przeciwdziałania przemocy w rodzinie to wówczas synonim polityki społecznej wobec rodziny. Polityka ta jest realizowana równolegle z innym politykami szczegółowymi: prorodzinną, senioralną, młodzieżowa, edukacyjną, zdrowotną oraz polityką wobec osób z niepełnosprawnościami i polityką wobec osób uzależnionych. Takie polityki pod względem zakresu w oczywisty sposób zachodzą na siebie, wskutek czego składają się na jedną całościową politykę społeczną ukierunkowaną na urzeczywistnienie określonej wizji ładu społecznego (Rymsza, 2015) .

\section{Geneza polityki publicznej przeciwdziałania przemocy w rodzinie}

Nie byłoby potrzeby działań publicznych, tworzenia polityk i interwencji, gdyby nie występowały problemy, które dotykają społeczeństwa. Według defini-

${ }_{5}^{5}$ Pogłębionej refleksji wymaga kwestia traktowania polityki przeciwdziałania przemocy w rodzinie jako polityki horyzontalnej, której realizacja polega na koordynowaniu różnych polityk szczegółowych adresowanych do tej samej grupy odbiorców z zastosowaniem różnych instrumentów oddziaływania (np. rozwiązań polityki karnej, polityki zdrowotnej, polityki socjalnej). 
cji problemu społecznego, jaką przedstawili Richard C. Fuller i Richard R. Myers, ,problemem społecznym są warunki, które definiowane są przez znaczącą liczbę osób, jako naruszenie [deviation] podzielanych przez nie norm społecznych. Obiektywne warunki są możliwym do weryfikacji stanem rzeczy, którego istnienie i rozmiary (proporcje) mogą być sprawdzone przez bezstronnych i wykwalifikowanych obserwatorów, na przykład stan obronności kraju, trendy w poziomie urodzin, bezrobocie, itp. Subiektywna definicja jest uświadomieniem sobie przez niektórych ludzi, że warunki te są zagrożeniem dla pewnych, podzielanych przez nich wartości” (Fuller, Myers, 1941, s. 320, za: Becker, (ed.). 1966, wstęp). Howard Becker uważa, że „pierwszy etap w rozwoju problemu społecznego przychodzi wówczas, gdy osoba lub grupa postrzega zespół obiektywnych warunków jako problematyczne, przedstawiając je jako zagrożenie albo ziarna przyszłych problemów" (Becker, 2011, s. 12, za: Zybała, 2012, s. 47). Odpowiedzialni za zarządzenie państwem zaczynają zazwyczaj zajmować się problemami, tworzą plany ich rozwiązania, gdy powstaje pewna masa krytyczna w postaci presji społecznej albo presji grup interesów. Czasami jest to presja wynikająca z widocznych skutków danego problemu.

Instytucjonalizacja polityki walki z przemocą domową postępowała stopniowo. W latach osiemdziesiątych i dziewięćdziesiątych XX wieku w wielu państwach różne środowiska i organizacje inicjowały debatę publiczną na temat przemocy wobec dzieci oraz kobiet i szeroko rozumianych praw człowieka. Działania organizacji walczącej o prawa kobiet, liczne publikacje naukowe i doniesienia prasowe, działania legislacyjne na poziomie międzynarodowym i krajowym, inicjatywy prospołeczne w zakresie pomocy dzieciom krzywdzonym i maltretowanym kobietom doprowadziły do zaliczenia przemocy w rodzinie do obszaru poważnych problemów społecznych w wymiarze międzynarodowym i do stopniowego włączania problematyki przeciwdziałania przemocy do interwencji instytucjonalnych wspólnoty międzynarodowej i państw narodowych ${ }^{6}$.

Początek refleksji naukowej nad kwestiami definiowanymi współcześnie jako problemy społeczne datujemy na przełom XIX i XX wieku, od kiedy procesy industrializacji i urbanizacji zmieniły ówczesne społeczeństwa. Gwałtowne przemiany technologiczne, ekonomiczne i społeczno-kulturowe, jakie dokonały się w XX wieku, doprowadziły do przeobrażeń w niemal każdej sferze życia społecznego, przyczyniając się do przeobrażenia starych i powstania no-

${ }^{6}$ Podczas Międzynarodowej Konferencji na rzecz Kobiet w Nairobi w 1985 r. oraz odbywającej się w tym samym czasie konferencji organizacji pozarządowych uznano przemoc wobec dzieci za poważny problem międzynarodowy, a przemoc wobec kobiet — za formę dyskryminacji. Parlament Europejski uznał, iż przemoc jest pogwałceniem prawa człowieka do życia, bezpieczeństwa osobistego, wolności, godności oraz fizycznej i umysłowej integralności, a tym samym stanowi przeszkodę dla pełnego rozwoju jednostek. Zob. Szymańczak, (2000, s. 6). 
wych problemów społecznych. W obliczu tych nowych wyzwań szczególną rolę odgrywały nauki społeczne, które w sposób naturalny stanowiły odpowiedź na potrzebę zrozumienia natury problemów społecznych. W obszarze analizy problemów społecznych wiek XIX to głównie domena polityki i publicystyki, a dopiero w XX wieku dominującą rolę zaczęła odgrywać socjologia, w ramach której nastąpił rozkwit analiz socjologicznych (Kudlińska, 2014, s. 138).

W tak zarysowanym kontekście społeczno-politycznym końca wieku XIX i XX wieku możliwe stało się publiczne prezentowanie danych, które prowadziły do konkluzji, że stosowanie różnych form dyskryminacji i przemocy wobec dzieci i kobiet stanowi poważny problem społeczny. Przyczyniło się do tego kilka czynników, wśród których wymienić można rozwój ruchów feministycznych, medycyny (medycyna sądowa, kryminologia), opieki zdrowotnej, pomocy społecznej i opieki socjalnej, stopniową demokratyzację różnych dziedzin życia oraz rozwój i legislację problematyki praw człowieka (Jarosz, 1999, s. 220). Wydawać się może, że przemoc wobec członków rodziny została odkryta przez opinię publiczną, prawników, psychologów i pracowników socjalnych, następnie zaś badaczy dziejów tego zjawiska dopiero w ostatnim dwudziestopięcioleciu XX wieku w konsekwencji rewolucji społecznej lat sześćdziesiątych i działań ruchów feministycznych. Na kształt budowy systemu międzynarodowego i systemów lokalnych przeciwdziałania przemocy w rodzinie wpływ miały czynniki, które wystąpiły w różnych krajach, środowiskach i ośrodkach, stąd też $\mathrm{w}$ celu pokazania kontekstu przedstawione zostaną wybrane elementy tego procesu, ważne również z punktu widzenia sytuacji w Polsce.

Analizując historię kształtowania się systemu upubliczniania problemu przemocy wobec kobiet i dzieci oraz ich ochrony przed krzywdzeniem, na pierwszy plan wysuwa się wkład medyków - w tym przede wszystkim medyków sądowych, w rozwój technik diagnostycznych oraz terapeutycznych wobec najmłodszych, a w literaturze fachowej pojawiały się pierwsze opracowania naukowe na temat chorób dziecięcych i problematyki ich wychowania (Stoba, Sroka, 2002, s. 245-249). W 1860 roku lekarz medyk sądowy Auguste Ambroise Tardieu opublikował pracę pod tytułem Étude médico-légale sur les sévices et mauvais traitements exercés sur des enfants („Sądowe studium na temat okrucieństwa wobec dzieci i złego ich traktowania"), w której opisał 32 przypadki dzieci będących ofiarami zamierzonych i nieprzypadkowych urazów, czego 18 zakończonych śmiercią. W kilka lat później pisząc Étude médico-légale sur l'infanticide („Sądowe studium na temat dzieciobójstwa”), przeanalizował szczegółowo 60 przypadków dzieciobójstwa. Tardieu podejmował też kwestie pracy dzieci $\mathrm{w}$ fabrykach i kopalniach, pracy wielogodzinnej oraz wykonywanej w koszmarnych warunkach, opisywał również tragiczne konsekwencje zdrowotne takiej ekonomicznej eksploatacji dzieci (Marciński, 2005, s. 33). Prace Tardieu oraz kilku innych lekarzy francuskich, takich jak Bernard czy Lacassagne, na temat przemocy seksualnej wobec dzieci były znane także Zygmuntowi Freu- 
dowi. W 1896 roku opublikował on trzy artykuły na temat teorii uwiedzenia, w której dowodził, że to wykorzystywanie seksualne w dzieciństwie może być przyczyną histerii dorosłych pacjentek (Włodarczyk, 2014, s. 34; zob. też Jarosz, 2009, s. 113). W Polsce w 1908 roku na łamach „Przeglądu Lekarskiego” temat podjął medyk sądowy i kryminolog Leon Wachholz, publikując artykuł zatytułowany Dzieci jako ofiary znęcania się rodziców (Theiss, 1995). Opisując pracę Tardieu i innych, Ewa Jarosz konkluduje: „[...] odkryte wtenczas prawdy o ciemnych stronach natury ludzkiej były na tyle szokujące, że badania nad przemocą zostały porzucone. Jak można sądzić, doniesienia i opisy Tardieu na temat maltretowania dzieci przez rodziców czy pierwotne interpretacje Freuda na temat wczesnodziecięcych źródeł poważnych problemów psychicznych znacząco wyprzedziły gotowość świata naukowego oraz gotowość opinii społecznej do przyjęcia w swojej świadomości istnienia tego problemu - uznania jego występowania. W rezultacie naukowe zainteresowanie zjawiskiem przygasło na prawie 100 następnych lat, choć sporadyczne wzmianki na ten temat pojawiały się w kolejnych latach zarówno w literaturze medycznej, jak i psychologicznej" (Jarosz, 2009) ${ }^{7}$.

Impulsem do ponownego zainteresowania problemami krzywdzenia dzieci i kobiet, a w szerszej perspektywie - przemocy w relacjach rodzinnych, był intensywny rozwój systemu opieki i pomocy społecznej, jaki nastąpił po zakończeniu II wojny światowej. Potrzeba kompensacji problemów, jakie dotykały społeczeństwa doświadczone działaniami wojennymi, spowodowały stopniowe otwieranie się na kwestie przemocy w rodzinie. Ważnym elementem aktywizującym i wzmacniającym była też działaalność środowisk feministycznych drugiej fali udzielających się $w$ ramach ruchu wyzwolenia kobiet oraz intensywny rozwój systemu ochrony praw człowieka (również sytemu ochrony praw dziecka) (Kwietniewska, 2013, s. 22). Renesans zainteresowania problematyką krzywdzenia dzieci i przemocy wobec kobiet (badanych i opisywanych jeszcze rozłącznie) przypada na lata sześćdziesiąte i siedemdziesiąte XX wieku. Ważną pozycją okazało się opublikowane w roku 1962 doniesienie z badań Henry'go Kempego i jego współpracowników The Battered Child Syndrome („Syndrom dziecka bitego"), w którym opisywano przypadki maltretowania dzieci, w nim

${ }^{7} \mathrm{Na}$ potwierdzenie tego Autorka przytacza publikacje przedstawicieli medycyny, jak Sherwood czy neurochirurdzy Ingraham i Matson, którzy badali i opisywali przypadki wylewów podtwardówkowych u dzieci, a także przykłady dokumentowania urazów nieprzypadkowych u dzieci, jak opublikowanie w 1929 r. pierwszego zdjęcia rentgenowskiego kośćca maltretowanego dziecka. Temat krzywdzenia dzieci poza problematyką wykorzystywania seksualnego podejmowany był w literaturze początku XX w. Przykładem mogą być prace Jacobsona, który w 1912 r. pisał o przemocy fizycznej w kontekście jej popularności jako tematu w prasie, czy von Levetzowa, który w 1934 r. zwrócił uwagę na psychologiczne krzywdzenie dziecka. O popularności tematu w środowiskach naukowych świadczyć może fakt, że między 1900 a 1940 rokiem tematyce przemocy fizycznej nad dzieckiem poświęcono ok. 20 prac naukowych — doktoratów. 
też użyto terminu syndrom dziecka maltretowanego (the battered child syndrom) (Kempe, Silverman, Steele, Droegenmuller, Silver, 2005, s. 11-20). Wnioski zawarte w prezentacji Kempego i jego współpracowników rozpętały wokół tematu prawdziwą burzę - w sensie zarówno naukowym, jak i społecznym. Jak lawina ruszyły naukowe badania nad zjawiskiem i dość szybko wykroczyły poza medyczne ujęcie problemu. Tematem zajęli się psychiatrzy, psychologowie, socjologowie, historycy, antropolodzy. W tym czasie zaczęto też analizować różnorodne wymiary zjawiska krzywdzenia dzieci i kobiet, tak że lata siedemdziesiąte i osiemdziesiąte XX wieku określić można jako czas eksplozji kierunków i liczby badań prowadzonych w ramach wielu dyscyplin (Jarosz, 2009, s. 118).

Kolejnym ważnym elementem, który przyczynił się do wprowadzenia do agendy tworzenia narzędzi rozwiązywania problemów przemocy domowej, z całą pewnością była budowa systemu ochrony praw człowieka, jaki w obszarze prawa międzynarodowego nastąpił w XX wieku. Ochrona praw człowieka została osadzona na fundamentach tzw. systemu uniwersalnego Organizacji Narodów Zjednoczonych oraz systemu europejskiego, na który składają się akty Rady Europy i dla krajów Unii Europejskiej, akty prawa unijnego. System uniwersalny ONZ tworzy:

1. Karta Narodów Zjednoczonych, podpisana 26 czerwca 1945 roku, która $\mathrm{w}$ art.1 pkt 3 oraz w art. 55 (c) zawiera klauzule dotyczące zakazu dyskryminacji (Karta..., 1947)

2. Powszechna Deklaracja Praw Człowieka

3. Rezolucja Zgromadzenia Ogólnego ONZ 217 A (III) przyjęta i proklamowana w dniu 10 grudnia 1948 roku;

4. Konwencja o prawach dziecka z 1989 roku;

5. Konwencja w sprawie likwidacji wszelkich form dyskryminacji kobiet z dnia 18 grudnia 1979 roku;

6. Deklaracja o Eliminacji Przemocy wobec Kobiet z dnia 20 grudnia 1993 roku;

7. Rezolucja 48/104 Zgromadzenia Ogólnego;

8. Rezolucja A/54/4 Zgromadzenia Ogólnego ONZ — Protokół Fakultatywny do Konwencji w sprawie likwidacji wszelkich form dyskryminacji kobiet z dnia 6 października 1999 roku;

9. Dokumenty Rady Europy:

- Rekomendacja Komitetu Ministrów Rec. (2002) 5 w sprawie ochrony kobiet przed przemocą z dnia 30 kwietnia 2002 roku,

- Rekomendacja Rady Europy 1450 (2000) dotycząca przemocy wobec kobiet w Europie,

- Rekomendacja Komitetu Ministrów R (90) 2 w sprawie reakcji społecznych na przemoc w rodzinie $\mathrm{z}$ dnia 15 stycznia 1990 roku,

- Rekomendacja Komitetu Ministrów R (85) 4 w sprawie przemocy w rodzinie z dnia 26 marca 1985 roku, 
- Europejska Konwencja o wykonywaniu prawa dzieci z dnia 25 stycznia $1996 \mathrm{roku}$,

- Konwencja o zapobieganiu i zwalczaniu przemocy wobec kobiet i przemocy domowej.

10. Dokumenty Parlamentu Europejskiego i Rady:

- Dyrektywa Parlamentu Europejskiego i Rady 012/29/UE z dnia 25 października 2012 roku, ustanawiająca normy minimalne w zakresie praw, wsparcia i ochrony ofiar przestępstw oraz zastępująca decyzję ramową Rady 2001/220/WSiSW (Archiwum MS, 2018).

Przedstawiony katalog aktów prawnych tworzy podwaliny systemu ochrony praw podstawowych, $\mathrm{tj}$. ochrona życia i godności ludzkiej oraz podstawowych wolności. Z nich wywodzi się wiele praw bardziej szczegółowych, a zapewnienie ich ochrony w aktach prawa międzynarodowego jest wyrazem trwającego rozwoju ochrony praw człowieka. W efekcie ich uszczegóławiania powstało wiele aktów uzupełniających te podstawowe i stały się one najważniejszymi dla ochrony określonych praw i grup społecznych (Bińczyk-Missala, 2008, s. 14). Problem przemocy wobec dzieci i kobiet wkroczył także na arenę międzynarodową. Wszystkie kraje członkowskie ONZ uczestniczące w IV Światowej Konferencji na rzecz Kobiet w Pekinie w 1995 roku zostały zobligowane do zebrania statystyk oraz opracowania i przedłożenia własnych planów eliminacji przemocy w relacjach rodzinnych.

Trzecim elementem przebudowy społecznej świadomości i akceptacji dla uznania przemocy w rodzinie za problem społeczny była działalność organizacji feministycznych lat sześćdziesiątych i siedemdziesiątych XX wieku. Jak pisze Anne Clark: „Przed dekadą lat siedemdziesiątych sądy oraz funkcjonariusze policji wciąż postrzegali bicie żony jako trywialne wykroczenie - policjant mógł nakazać mężowi, by się uciszył, a żonie, by starała się go nie irytować, i sprawy rzadko kończyły się na sali sądowej. Kultura popularna portretowała bitą żonę $\mathrm{w}$ formie żartobliwej, a psychiatrzy opisywali przemoc domową jako patologię dotyczącą klas niższych albo jako tylko jednostkowe przypadki. Uogólniając, zaprzeczano, by problem istniał lub go usprawiedliwiano" (Clark, 2011, s. 193; za: Klich-Kluczewska, 2015, s. 180). Działania środowisk feministycznych w krajach Europy Zachodniej i Stanów Zjednoczonych koncentrowały się na popularyzacji idei respektowania praw kobiet i dzieci, ale też miały wymiar praktyczny, wiele organizacji świadczyło pomoc materialną i prawną dzieciom oraz matkom doświadczającym molestowania i gwałtu. Prowadzone były schroniska dla kobiet ${ }^{8}$, a w konkretnych sytuacjach przemocowych wspierano

${ }^{8} \mathrm{~W}$ latach 70. XX w., E. Pizzey otworzyła na przedmieściach zachodniego Londynu jedno z pierwszych we współczesnym świecie schronisk dla kobiet będących ofiarami przemocy. Działalność ta zbiegła się w czasie z powstaniem Narodowej Federacji na rzecz Obrony Kobiet w 1974 r. Organizacja skupiała blisko 40 schronisk dla ofiar przemocy w Wielkiej Brytanii, a także pierwszy organ krajowy działający w obszarze prawa i polityki 
ofiary, żądając dla nich ochrony przez służby policyjne, prowadzono pierwsze telefoniczne pogotowia kryzysowe dla ofiar, a gromadzona przez nie dokumentacja przypadków przemocy wobec kobiet dowiodła ponadto, że problem ten nie dotyczył wyłącznie rodzin z klasy robotniczej, jak powszechnie sądzono (Klich-Kluczewska, 2015, s. 182). Jednocześnie rozwijała się feministyczna refleksja teoretyczna na temat tego zjawiska, czego wyrazem były teorie Amerykanki Lenore Walker, której wydana w 1979 roku książka The Battered Woman uważana jest za jedną z pierwszych prób budowy spójnej teorii psychologicznej dotyczącej powstawania zależności przemocowej w rodzinie i sposobów jej przezwyciężania. Jej teoria cycle of violence, oparta na założeniach psychologii feministycznej, tłumaczyła obecność przemocy w rodzinie patriarchalną pozycją mężczyzny ${ }^{9}$, który ma czuć się zobligowany do stosowania przemocy w celu sprawowania i utrzymania pełnej kontroli nad pozostałymi członkami rodziny (Klich-Kluczewska, 2015, s. 182).

Podsumowując tę część rozważań, warto przytoczyć słowa Barbary Klich-Kluczewskiej: „Nie podważając rangi »przewrotu« późnych lat sześćdziesiątych oraz dekady lat siedemdziesiątych, który pozwala poukładać puzzle rozwoju wiedzy, w tym wiedzy o przemocy domowej, w spójną całość, musimy pamiętać, że na badania problematyki przemocy wobec członków rodziny składa się wiele wątków stanowiących część odmiennie rozwijających się ścieżek analitycznych, opierających się na różnych źródłach, inspiracjach teoretycznych, i wyrastających często $\mathrm{z}$ innego dyscyplinarnego korzenia. Różnymi bowiem ścieżkami podążają badacze przemocy wobec dziecka oraz najczęściej utożsamianej z przemocą domową, przemocy wobec kobiet" (Klich-Kluczewska, 2015, s. 181$)^{10}$. Kampanie zapoczątkowane pod koniec lat siedemdziesiątych i na początku osiemdziesiątych XX wieku wydobyły ze sfery tabu problem przemo-

na rzecz wsparcia kobiet i dzieci doświadczających przemocy domowej. Model zaproponowany przez Pizzy bardzo szybko rozprzestrzenił się w USA oraz innych krajach jako alternatywny sposób radzenia sobie z przemocą. Zob. www.womensaid.org.uk; Walker (2002, s. $81-102)$.

9 Dane $\mathrm{z}$ interwencji Policji dotyczących przemocy w rodzinie, analizy akt sądowych oraz liczne wyniki badań potwierdzają, że to mężczyźni zdecydowanie częściej są sprawcami przemocy domowej. Należy jednak zauważyć, że uwarunkowana płciowo przemoc mężczyzn wobec kobiet nie do końca znajduje potwierdzenie w rzeczywistości. Dowodzą tego odnotowywane w statystykach i aktach sądowych liczne przypadki przemocy kobiet wobec mężczyzn lub przemoc w związkach lesbijskich. Więcej na ten temat zob. Dominiczak (2000), Straus, Ramirez (2007, s. 281-290), George (1994, s. 137-159), Ard, Makadon (2011, s. 630-633).

${ }_{10}$ W literaturze przedmiotu od ponad 20 lat pojawiają się doniesienia o istnieniu związku między przemocą małżeńską a przemocą fizyczną wobec dzieci, a także między przemocą małżeńską a wykorzystywaniem seksualnym dzieci. Wyniki wielu badań potwierdzają istnienie ścisłego związku między przemocą małżeńską a krzywdzeniem dzieci, przy czym krzywdzenie i zaniedbywanie dzieci występuje w około połowie rodzin, w których dochodzi do aktów przemocy między rodzicami. Zob. Browne, Dixon (2003). 
cy w rodzinie i zoperacjonalizowały tzw. mitologię przemocy domowej, w celu walki z niezrozumieniem tego zjawiska. Stereotypy dotyczące przemocy w relacjach rodzinnych wpływają na jej percepcję w społeczeństwie. Często powiązane $\mathrm{z}$ wiarą $\mathrm{w}$ sprawiedliwy świat zwalniają ludzi, w tym także służby pomocowe, z odpowiedzialności za przeciwdziałanie przemocy, której są świadkami. Tak utrwalone społecznie przekonania prowadziły bowiem do usprawiedliwiania działania sprawców, pomniejszania znaczenia samej przemocy czy odbierały ofierze wiarę w możliwość uzyskania pomocy i przerwania przemocy (Lelek-Kratiuk, 2014, s. 98).

\section{Polityka publiczna przeciwdziałania przemocy w rodzinie w Polsce}

Podobnie jak w Europie Zachodniej i Stanach Zjednoczonych — w Polsce budowa systemu przeciwdziałania przemocy domowej poprzedzona była „,orastaniem" społeczeństwa do nazwania i identyfikacji przemocy w rodzinie jako poważnego problemu społecznego. Liczni autorzy podają, że proces publicznego ujawniania tego problemu nastąpił po 1989 roku, wraz z przemianami politycznymi, które stworzyły klimat do podejmowania aktywności obywatelskiej (Szymańczak, 2000; Bołdyrew, 2009, s. 1-8; Ziemierski, 2010; Mazur, 2015; Wiślicz, 2012; Zybała, 2014). Skromny wkład w rozwój badań i kształtowanie świadomości szkodliwości przemocy w rodzinie wynikał w powojennej Polsce zapewne ze względów ideologicznych. Badająca problem tabuizacji problemów przemocy domowej w Polskiej Rzeczypospolitej Ludowej Klich-Kluczewska ocenia: „Jest to jeden z najbardziej dosłownych obszarów przemilczeń, dla którego trudno jednoznacznie określić instancje tabu oraz szkicować ścieżki transformacji wyobrażeń. Jest to szczególnie trudne w wypadku lat 1956-1989, ponieważ okres powojennego dziesięciolecia łatwiej wpisywać w tradycję wojennej i powojennej, a następnie stalinowskiej kultury przemocy i społecznego chaosu" (Klich-Kluczewska, 2015, s. 184). Pewien obraz podejścia do przemocy w rodzinie i stopień akceptacji społecznej dla tego zjawiska w PRL uzyskać można na podstawie analizy akt sądowych spraw związanych z oskarżeniem o przestępstwo „fizycznego i moralnego znęcania się", a także akt rozwodowych i akt spraw dotyczących pozbawienia praw rodzicielskich ${ }^{11}$. Innym ciekawym

${ }^{11}$ Przyjąć należy, że są to dane przedstawiające pewien fragment rzeczywistości, oparty na przykładach spraw drastycznych, których ciężar gatunkowy był znaczny, skoro prokurator decydował się kierować do sądu akt oskarżenia przeciwko sprawcy znęcania się — wiele $\mathrm{z}$ nich na etapie prokuratorskim kończyło się bowiem umorzeniem postępowania. 
źródłem wiedzy są teksty i listy czytelników zamieszczanie w popularnej wówczas prasie (Słowiński, 2013, s. 51-82) ${ }^{12}$ oraz publikacje, których autorzy podejmowali próby weryfikacji tezy o narastającym kryzysie rodziny i problemie alkoholowym (Kosiński, 2002, 2006, 2008; Gapiński, 2008). Obraz, jaki wyłania się z badań tego okresu, skłania do refleksji, że w PRL przemoc była zupełnie przemilczana. Według niektórych socjologów przemoc domowa w PRL, należąc do przestrzeni rodziny, staje się automatycznie „obszarem swoiście rozumianego tabu". To również miało być powodem, dla którego funkcjonariusze Milicji Obywatelskiej ${ }^{13}$ nie reagowali zdecydowanie i skutecznie $w$ takich sprawach (Klich-Kluczewska, 2015, s. 185). Przemoc fizyczna w rodzinie stawała się ewentualnie sprawą publiczną wówczas, gdy kończyła się tragicznie śmiercią lub trwałym okaleczeniem ofiary (Klich-Kluczewska, 2015, s. 191). Problem przemocy, jeżeli pojawiał się w przestrzeni publicznej, zestawiany był zazwyczaj z alkoholizmem, którego rozmiary stopniowo narastały. Spożywanie alkoholu w czasach PRL było normą, niezależnie od tego, czy robiono to w domu, w pracy, czy na ulicy. Poza formą ucieczki od szarej rzeczywistości i problemów państwa totalitarnego picie było często nieodzownym elementem spędzania wolnego czasu (Kosiński, 2008, s. 453) ${ }^{14}$. Nadużywanie alkoholu niejednokrotnie stanowiło przyczynę różnych patologii i dramatów rodzinnych, nierzadko także rozpadu rodziny. Alkoholicy, którzy awanturowali się i bili swoje żony, najczęściej pozostawali bezkarni. Nieraz to same bite żony broniły swych mężów, a wiązało się to z ogólnym przyzwoleniem na picie alkoholu (Słowiński, 2013, s. 71). Istnienia silnego związku pomiędzy nadużywaniem alkoholu i przemocą stosowaną wobec domowników została ona poddana kryminalizacji, czego konsekwencją była nie tylko bezkarność trzeźwych sprawców, ale i brak zaangażowania ze strony instytucji porządku publicznego, wymiaru sprawiedliwości i pomocy społecznej. Polskie instytucje państwowe pozostawiały ofiary

12 Autor podaje, że rocznie do „Przyjaciółki” nadsyłano około 130 tys. listów. Na potrzeby artykułu badaniom poddanych zostało 2360 listów, które ukazały się w tym czasopiśmie w latach 1956 - 1970. Na ich podstawie wytypowano najbardziej palące problemy życia codziennego, którymi były: sprawy mieszkań, służba zdrowia, kłopoty w pracy, nadużywanie alkoholu i tzw. buble.

${ }_{13} \mathrm{~W}$ PRL nie stosowano w ogóle pojęcia przemocy domowej. Aż do czasu wejścia w życie kodeksu karnego z 1932 r. na ziemiach polskich stosowało się pojęcia udręczenia, męczarni i srogości. Funkcjonowały owe np. w kodeksach karnych Królestwa Polskiego jako części Rosji; w zaborze austriackim — stosowano pojęcie ukrzywdzenia cielesnego w wyniku nadużywania prawa karcenia. W Rzeszy z kolei znęcanie się to ciężki kwalifikowany uraz cielesny. W kodeksie z 1932 r., obowiązującym do 1969 r., przemoc wobec członków rodziny regulował art. 246.

${ }^{14}$ Przedstawiciele władz winą za taki stan rzeczy obarczali II Rzeczpospolitą, a także okupanta, który miał rozpijać polskie społeczeństwo. Komuniści nie robili jednak prawie nic, by zapobiegać alkoholizmowi, a społeczeństwo niestety przykład brało również z góry. 
przemocy bez realnej opieki i pomocy. Problem przemocy w rodzinie był więc problemem prywatnym (Klich-Kluczewska, 2015, s. 216) ${ }^{15}$.

Zainteresowanie przemocą $\mathrm{w}$ rodzinie, jakie odnotować można na świecie w licznych gremiach naukowych w latach siedemdziesiątych i osiemdziesiątych $\mathrm{XX}$ wieku, przełożyło się na pojawianie się tego problemu w refleksji naukowej i publikacjach rodzimych kryminologów, prawników, pedagogów, socjologów i psychologów społecznych (Zakrzewski, 1973; Akoliński, 1975; Przestępczość..., 1979; Strzembosz, 1979; Tobis, 1980; Kwaśniewski, 1979; Szwarc, 1984; Jarosz, 1987; Wódz, 1988 — za: Klich-Kluczewska 2014). Wraz z rozwojem badań naukowych samo zjawisko przemocy w rodzinie dostrzeżone zostało w pragmatyce wymiaru sprawiedliwości, czego wyrazem było stanowisko Sądu Najwyższego z 1976 roku, który w wytycznych dla sądów niższych instancji zastosował wykładnię, że przestępstwo znęcania się godzi w trwałość rodziny i przyczynia się do jej rozbicia, a co za tym idzie — osłabienia jej funkcji wychowawczych (Klich-Kluczewska, 2015, s. 217). Równolegle w latach osiemdziesiątych nastąpiła także wyraźna aktywizacja działań społecznych, formalnych i nieformalnych, służących wspomaganiu kobiet i dzieci zagrożonych przemocą. Jako przykłady przywoływana już Klich-Kluczewska (2015, s. 217) podaje Komitet Ochrony Praw Dziecka powołany w 1981 roku z inicjatywy prof. Marii Łopatkowej, a także działania pomocowe psycholożki Anny Lipowskiej-Teusch, która zaangażowała się na rzecz pomocy kobietom dręczonym przez członków rodziny, świadcząc pomoc psychologiczną w Klinice Toksykologii Akademii Medycznej w Krakowie. W latach osiemdziesiątych XX wieku założyła ona Towarzystwo Interwencji Kryzysowej (formalnie zarejestrowane w 1990 r.). Następstwem tego było powstanie - dzięki porozumieniu wojewody oraz rektorów Uniwersytetu Jagiellońskiego i Akademii Medycznej — Ośrodka Interwencji Kryzysowej (Portret kobiety..., 2001). Generalnie w latach osiemdziesiątych XX wieku w działalności instytucji państwowych zagadnienia przemocy w rodzinie nie stanowiły wyodrębnionego problemu ani obszaru zorganizowanej działalności pomocowej i zaradczej. Działania interwencyjne w związku z przypadkami ujawnianej, na przykład przez Milicję, przemocy domowej miały charakter nieskoordynowany i powielały się na przestrzeni czasu, nie przynosząc spodziewanych efektów. W wielu sytuacjach, mimo dramatyzmu poszczególnych przypadków i skali zjawiska, problematyka przemocy w rodzinie spychana była poza główny nurt działalności instytucji państwowych powołanych do ochrony porządku publicznego i świadczenia pomocy społecznej. Na bardzo niskim poziomie pozostawała także kwestia świadomości i wrażliwości społecznej wobec

15 Jeżeli dochodziło do postawienia sprawcy w stan oskarżenia, działo się to zazwyczaj w przypadku najbardziej brutalnych przestępstw, które odbijały się szerokim echem w prasie i społeczności lokalnej. Ze względu na „niepamięć” świadków lub „przebaczenie” sprawcy znaczna część spraw była umarzana, a w przypadku skazania sprawca mógł zostać objęty amnestią. Zob. Bednarzak (1974, s. 31-52). 
przemocy w rodzinie, natomiast siła oddziaływania stereotypów i brak wiedzy powodowały, że dla decydentów problem przemocy sprowadzał się do patologii, tzw. marginesu społecznego, a dla świadków przemocy w środowisku sąsiedzkim, pozostawał tematem tabu (Rymsza, 2016, s. 16). Wraz ze zmianą ustroju politycznego w Polsce, na początku lat dziewięćdziesiątych, zmieniło się też podejście do wielu kwestii społecznych, których nie postrzegano dotąd w perspektywie zagrożeń i problemów społecznych. W roku 1991 powołany został urząd Pełnomocnika Rządu do spraw Rodziny i Kobiet, a problem przemocy wewnątrzrodzinnej został wprowadzony do Narodowego Programu Rozwiązywania Problemów Alkoholowych, wiadomo bowiem było, że w wielu przypadkach przemoc ta wiązała się z nadużywaniem alkoholu w rodzinie: „Dzieci, współmałżonkowie i inni członkowie rodzin osób uzależnionych od alkoholu tworzą największą w Polsce, liczącą nie mniej niż 2 mln osób, populację o bardzo wysokim stopniu zagrożenia przemocą w rodzinie" (Mellibruda, 2006).

W Polsce lat dziewięćdziesiątych XX wieku historycznie wyróżnić można trzy nurty działań na rzecz przeciwdziałania przemocy domowej, dotyczące:

- ochrony dzieci przed krzywdzeniem i wykorzystaniem;

- feministycznych działań na rzecz ochrony praw kobiet i walki o tzw. równy status płci;

- rozwiązywania problemów alkoholowych.

Dwa pierwsze nurty mają długą tradycję, jak chociażby działalność Janusza Korczaka w obronie dzieci krzywdzonych, a także działalność Towarzystwa Przyjaciół Dzieci oraz Komitetu Ochrony Praw Dziecka. Z kolei nurt dotyczący rozwiązywania problemów alkoholowych w Polsce sięga działalności trzeźwościowej organizowanej już w XIX wieku, a Instytut Psychologii Zdrowia PTP (Państwowa Agencja Rozwiązywania Problemów Alkoholowych - PARPA ${ }^{16}$ ) zajmuje się tym problemem od ponad 30 lat. Jak twierdzi Jerzy Mellibruda, „od samego początku tej pracy przyjmowaliśmy jednak założenie, że wszelkie formy działania i zasoby, które będą powstawały, powinny być dostępne dla wszystkich ludzi doznających przemocy, a nie tylko dla tych, którzy żyją w rodzinach alkoholowych" (Mellibruda, 2006, s. 2). Przedsięwzięcia i działania podejmowane $\mathrm{w}$ ramach wymienionych nurtów prowadziły do stopniowej konsolidacji i instytucjonalizacji różnych polityk, gdzie w spektrum oczekiwanych rezultatów stawiano rozpoznanie, zapobieganie, wspomaganie/leczenie i ściganie wszelkich przejawów krzywdzenia i przemocy w rodzinie. Tworzenie poli-

${ }^{16} \mathrm{~W}$ wymiarze stanowienia prawa w latach 80 . XX w. uchwalono akt normatywny, który stanowi podstawę prawną funkcjonowania PARPA. Była to ustawa z dnia 26 października 1982 r. o wychowaniu w trzeźwości i przeciwdziałaniu alkoholizmowi, która do dzisiaj jest obowiązującym aktem prawnym. Agencja została utworzona na podstawie zarządzenia Ministra Zdrowia i Opieki Społecznej z dnia 29 czerwca 1993 r., jako agenda ministerstwa stanowiąca narzędzie pracy osoby pełniącej urząd Pełnomocnika Ministra Zdrowia ds. Profilaktyki i Rozwiązywania Problemów Alkoholowych. 
tyki przeciwdziałania przemocy domowej w Polsce oparte zostało na zasadach hybrydowego modelu tworzenia i implementacji polityk publicznych. Wiodącą rolę odgrywały organy władzy publicznej, które poprzez legislację i regulację konsolidowały zasoby instytucji centralnych, włączając interesariuszy poziomu wykonawczego administracji publicznej, samorządowej i organizacji pozarządowych. Politykę przeciwdziałania przemocy w rodzinie ulokowano co do zasady w dziale administracji rządowej realizującej politykę społeczną (Zybała, 2014, s. 6).

Pewna wstępna instytucjonalizacja polityki państwa jako polityki publicznej w dziedzinie przeciwdziałania przemocy nastąpiła w latach 1994-1995, kiedy to PARPA przygotowała koncepcję programu przeciwdziałania przemocy w rodzinach alkoholowych „Bezpieczeństwo w rodzinie” (Bezpieczeństwo $w$ rodzinie..., 2014) ${ }^{17}$, którego autorzy zakładali: (a) wprowadzenie do pragmatyki służbowego działania odpowiednich instytucji specyficznych procedur monitorowania i interwencji $\mathrm{w}$ sprawach przemocy w rodzinie; (b) przygotowanie i zainicjowanie procedur legislacyjnych uzupełniających istniejące braki w systemie prawnym, utrudniające skuteczne działania w zakresie przeciwdziałania przemocy w rodzinie; (c) zwiększenie liczby osób posiadających wiedzę i kompetencje praktyczne potrzebne do skutecznego radzenia sobie z problemami przemocy w rodzinie, wśród policjantów, sędziów i prokuratorów, kuratorów, pracowników socjalnych, pedagogów i pracowników służby zdrowia oraz członków gminnych komisji ds. przeciwdziałania alkoholizmowi; (d) zwiększenie liczby schronisk dla ofiar przemocy w rodzinie i punktów konsultacyjnych udzielających pomocy prawnej; (e) zwiększenie liczby specjalistycznych placówek (m.in. służby zdrowia) prowadzących programy pomocy psychologicznej dla ofiar przemocy w rodzinie i oddziaływań psychokorekcyjnych wobec sprawców; (f) wzmocnienie i rozwój stowarzyszeń i środowisk wzajemnej pomocy i samoobrony ofiar przemocy; (g) zwiększenie liczby gmin, w których są podejmowane lokalne inicjatywy służące pomocy dla ofiar, a działania gminnej komisji ds. przeciwdziałania alkoholizmowi obejmują interwencje wobec przemocy w rodzinie; (h) uzyskanie przyrostu danych empirycznych i wiedzy praktycznej na temat przemocy w polskich rodzinach oraz sposobów rozwiązywania problemów z nią związanych; (i) zmiana postaw i świadomości społecznej w zakresie przemocy w rodzinie, osłabienie stereotypów utrudniających zapobieganie przemocy i zwiększenie liczby informacji potrzebnych do obrony przed przemocą; (j) pozyskanie osób i instytucji znaczących dla życia społecznego do współpracy w zakresie przeciwdziałania przemocy w rodzinie oraz środków finansowych na realizacje niezbędnych działań (Mellibruda, 2006, s. 3). Efektem działań podejmowanych w ramach programu „Bezpieczeństwo w rodzinie” było powstanie nowych instytucji i organizacji, przeprowadzano kampanie związane

${ }^{17}$ Program zawierał diagnozę problemu przemocy w rodzinie. 
z przeciwdziałaniem przemocy i z pomocą jej ofiarom. Te instytucje to: Ogólnopolskie Pogotowie dla Ofiar Przemocy w Rodzinie „Niebieska Linia”, Studium Przeciwdziałania Przemocy w Rodzinie (1995 r.), Ogólnopolskie Porozumienie Osób, Instytucji i Organizacji Pomagających Ofiarom Przemocy w Rodzinie „Niebieska Linia” (1996 r.), Kampania Ogólnopolska „Powstrzymać Przemoc Domową” zorganizowana przez PARPA (1997 r.), Kampania „Dzieciństwo bez Przemocy" (2000 - 2001). W 1995 roku PARPA razem z Parlamentarną Grupą Kobiet zorganizowała konferencję w Sejmie dotyczącą przeciwdziałania przemocy w rodzinie. Konferencja zakończyła się uchwaleniem „Polskiej deklaracji w sprawie przemocy w rodzinie". Z kolei w roku 1996 przeprowadzono nowelizację Ustawy o wychowaniu w trzeźwości i przeciwdziałaniu alkoholizmowi, przekazując samorządom gminnym większość zadań i środków finansowych, a w tym również zadanie przeciwdziałania przemocy w rodzinie jako zadanie własne gmin (Zalewski, Janułajtys, 2017, s. 244). Jednocześnie na poziomie rządowym w 1997 roku podjęto działania w ramach programu „Przeciw Przemocy - Wyrównać Szanse" realizowanego przy współudziale United Nations Development Programme (UNDP). 28 sierpnia 1997 roku został podpisany dokument programowy, w którego ramach dofinansowane zostały trzy organizacje pozarządowe, które utworzyły pierwsze ośrodki pomocy ofiarom przemocy (Program „Przeciw przemocy...” 1998) ${ }^{18}$.

Opierając się na pierwszych doświadczeniach dotyczących przeciwdziałania przemocy $\mathrm{w}$ rodzinie oraz na wiedzy osób pomagających ofiarom przemo-

18 Po wyborach parlamentarnych we wrześniu 1997 r. nowoutworzony rząd powołał urząd Pełnomocnika Rządu ds. Rodziny, który przyjął odpowiedzialność za realizację Programu „Przeciw przemocy - wyrównać szanse” ze strony Rządowej. Przewidywał on utworzenie dziewięciu ośrodków dla ofiar przemocy rodzinnej, w których miała być udzielana kompleksowa pomoc. Klientki ośrodków miały m.in. otrzymywać pożyczkę na usamodzielnienie się. Program rozpoczęła kampania billboardowa przeciwko przemocy domowej, uświadamiająca, iż zjawisko przemocy w rodzinie jest niestety częścią polskiej codzienności. Kampania ta, rozpoczęta w listopadzie 1997 r., miała znaleźć ciąg dalszy w programie realizowanym przez rząd polski, ONZ i organizacje pozarządowe. Zgodnie z umową podpisaną w sierpniu 1997 r. między Pełnomocnikiem ds. Rodziny i Kobiet a UNDP, każda ze stron zobowiązała się wyasygnować na realizację programu w latach 1997-1999 po 300 tys. USD. Pierwszym krokiem - oprócz wyposażenia schronisk - miało być szkolenie wolontariuszy. Program powstał na podstawie pekińskiej Platformy Działania z 1995 r. Był adresowany do kobiet i dzieci - ofiar przemocy rodzinie. Miał na celu stworzenie w Polsce podstaw prawnych instytucjonalnego systemu pomocy dla maltretowanych kobiet i zapewnienie im skutecznej ochrony. Centra były zobowiązane nieść klientom kompleksową pomoc: medyczną, prawną, psychologiczną i ekonomiczną. Istotą programu było stworzenie kobietom - ofiarom przemocy możliwości odzyskania pełni praw społecznych i ekonomicznych. Pierwsze ośrodki, wbudowane w lokalne struktury społeczne, miały funkcjonować, współpracując z lokalnym samorządem i zapewnić ochronę 180 kobietom i 360 dzieciom. Zob. Niebieska linia https://www.niebieskalinia.pl/pismo/wydania/dostepne-artykuly/4463-w-drodze (data dostępu: 12.01.2020). 
cy w rodzinie, a także na rozwiązaniach wprowadzonych w państwach, gdzie programy przeciwdziałania tego typu przemocy były bardziej zaawansowane, dostrzeżono konieczność zastosowania instrumentów podnoszących sprawność działania służb stykających się z ofiarami przemocy w rodzinie. Był to początek prac nad tworzeniem warunków do systemowego, interdyscyplinarnego podejścia do tej problematyki. Pierwsze prace nad stworzeniem odpowiednich procedur dla Policji podjęto w środowisku pracowników Państwowej Agencji Rozwiązywania Problemów Alkoholowych i przedstawicieli Policji już w 1994 roku, kiedy to powołany został zespół roboczy, w którego skład weszli reprezentanci PARPA, Wydziału Prewencji Komendy Stołecznej Policji, Batalionu Patrolowo-Interwencyjnego Komendy Stołecznej Policji i Warszawskiego Stowarzyszenia Abstynenckiego. Po opracowaniu założeń wstępnych co do kształtu procedury interwencji Policji w sytuacji przemocy w rodzinie, nazwanej procedurą „Niebieskie Karty”, w marcu 1997 roku przystąpiono do jej praktycznego testowania i pilotażu. Zadanie to powierzono Komendzie Stołecznej Policji, która wskazała do realizacji Komendę Rejonowa Policji IV — Warszawa-Ochota.

Pilotaż trwał trzy miesiące i realizowany był dwuetapowo. W pierwszym etapie trwającym dwa tygodnie przeprowadzono szkolenia policjantów służb patrolowo-interwencyjnych, dyżurnych, dzielnicowych, a następnie policjanci razem z obserwatorami cywilnymi pracującymi na co dzień z ofiarami przemocy $\mathrm{w}$ rodzinie, przeszkolonymi przez PARPA, podejmowali interwencje z udziałem cywilnych specjalistów w przypadkach zgłoszenia przemocy w rodzinie. Analizowano przydatność dokumentacji sporządzanej $\mathrm{w}$ trakcie interwencji, reakcje uczestników na zastosowane procedury, a także możliwości stosowania wypracowanych rozwiązań w odniesieniu do dynamiki konkretnych interwencji. Po ewaluacji przyjętych rozwiązań przystąpiono do drugiego etapu pilotażu. Skrócono w treści i układzie graficznym stosowne w pierwszym etapie pilotażu formularze, tak by zyskać na ich przejrzystości i czytelności. W trakcie trwających trzy tygodnie służb podejmowano w dalszym ciągu wspólne interwencje, w czasie których używano poprawionych formularzy, a dzielnicowi razem z pracownikami cywilnymi odwiedzali rodziny, w których w czasie wcześniejszych interwencji założono „Niebieską Kartę”.

Po przeprowadzeniu pilotażu sporządzona została opinia dla dyrektora PARPA i dyrektora Biura Prewencji KGP, zawierająca rekomendację do upowszechnienia procedury „Niebieskich Kart” w całym kraju (Sasal, 2001, s. 7). Wdrożeniem procedury „Niebieskie Karty” w Policji i jednostkach pomocy społecznej zajęły się powołane na początku 1998 roku trzyosobowe zespoły koordynatorów wojewódzkich. Koordynatorami mogli być przedstawiciele Komend Wojewódzkich Policji, pełnomocnicy wojewodów ds. rozwiązywania problemów alkoholowych oraz przedstawiciele Wojewódzkich Zespołów Pomocy Społecznej. Po szkoleniu, jakie odbywało się w Centrum Szkolenia Policji w Legionowie, koordynatorzy wojewódzcy przeszkolili 17530 policjantów, 7483 pracowników 
socjalnych, 4011 członków Gminnych Komisji Rozwiązywania Problemów Alkoholowych, 1223 koordynatorów gminnych programów profilaktyki rozwiązywania problemów alkoholowych, 2327 pedagogów, psychologów, kuratorów zawodowych, lekarzy i księży (10 lat ustawy..., 2015). Zwieńczeniem tej pracy było wprowadzenie z dniem 1 października 1998 roku do użytku służbowego Policji w całym kraju procedury interwencji Policji w sytuacji przemocy w rodzinie procedura opracowana została i zatwierdzona przez PARPA i Biuro Prewencji Komendy Głównej Policji (Kozłowska 2015, s. 6) ${ }^{19}$. Wprowadzając procedurę „Niebieskie Karty”, zakładano, że przeciwdziałanie przemocy domowej powinno być oparte na współdziałaniu wielu interesariuszy, którzy realizując swoje ustawowe uprawnienia, skutecznie stworzą system (system ogólnokrajowy, systemy lokalne), którego celem będzie zwiększenie poczucia bezpieczeństwa osób doświadczających przemocy, co w efekcie przyczyni się do zmniejszenia skali tego zjawiska (Gierszewski, 2019, s. 181).

Doświadczenia wynikające $\mathrm{z}$ budowania systemu przeciwdziałania przemocy w rodzinie, oparte na doświadczeniach i inicjatywach organizacji pozarządowych, wspierane dodatkowo przez działania realizowane w ramach procedury „Niebieskie Karty”, a także różne programy rządowe ${ }^{20}$ znalazły swoje bardzo mocne instytucjonalne wsparcie w uchwaleniu w 2005 roku ustawy o przeciwdziałaniu przemocy w rodzinie (dalej UPPR) (Ustawa z dnia 21 listopada 2005 r.) ${ }^{21}$. Ustawa ta stanowiła nowe rozwiązanie w prawie polskim, gdyż wcześniej problematyka dotycząca przemocy $\mathrm{w}$ rodzinie była uregulowana w wewnętrznych przepisach Policji, pomocy społecznej oraz gminnej komisji rozwiązywania problemów alkoholowych (Kozłowska, 2015, s. 10). Ustawa wprowadzała do obiegu prawnego definicję przemocy w rodzinie, określała prawa ofiar, wyodrębniała kierunki działań (działania dotyczące budowy systemu wsparcia, ochrona i pomoc ofiarom, oddziaływanie korekcyjno-wychowawcze wobec sprawcy, podnoszenie świadomości społecznej na temat przyczyn i skutków przemocy - pomoc ofiarom - interwencja - wsparcie — profilaktyka) i narzędzia do ich realizacji (,twarde” - prawo, przymus, represja, „miękkie” - edukacja, doradztwo, pro-

19 Ostatnim etapem wprowadzania do stosowania w Policji procedury „Niebieskie Karty” było wydanie Zarządzenia nr 25 Komendanta Głównego Policji z dnia 10 listopada 1998 r. w sprawie sposobu przeprowadzania interwencji domowej przez policjantów wobec przemocy w rodzinie pod nazwą „Niebieskie Karty”. Na przestrzeni kolejnych lat procedura była zmieniana i udoskonalana.

${ }^{20}$ Realizowane w ramach krajowych programów, strategii itp., które dotyczyły m.in., polityki społecznej i polityki na rzecz kobiet, zawierały cząstkowe działania na rzecz przeciwdziałania przemocy w rodzinie (np. kształtowanie polityki prorodzinnej, rola i zadania pełnomocnika ds. równego traktowania, geneza regulacji konstytucyjnych dot. ochrony rodziny i inne).

${ }^{21}$ Konieczność wprowadzenia krajowej regulacji prawnej dotyczącej przemocy w rodzinie wynikała z międzynarodowych zobowiązań Polski, przepisów prawa międzynarodowego i przynależności do Rady Europy. 
filaktyka, perswazja, informacja, wsparcie psychologiczne, materialne), precyzowała rolę samorządów w systemie przeciwdziałania przemocy (Gierszewski, 2019, s. 183). Na bazie ustawy rząd przyjął Krajowy Program Przeciwdziałania Przemocy w Rodzinie, w którym zakładano wiele działań w zakresie profilaktyki, prewencji, prawa, zdrowia, edukacji i pracy socjalnej. Zobowiązano samorządy do silniejszego zaangażowania $\mathrm{w}$ jego realizację przez obowiązek tworzenia w gminach zespołów interdyscyplinarnych, łączących wszystkich interesariuszy problemu przemocy (Zybała, 2014, s. 3) 22. Zespół Interdyscyplinarny, w konkretnych przypadkach, ma możliwość tworzenia grup roboczych, których przedstawiciele spotykają się z osobami zarówno doznającymi przemocy, jak i stosującymi przemoc. Grupy te we współpracy z rodziną pracują nad zaplanowaniem i realizacją konkretnej pomocy oraz jej monitoringiem ${ }^{23}$.

Nowelizacja UPPR, jaka nastąpiła w 2010 roku, rozbudowała obowiązek realizacji procedury „Niebieskie Karty”, nakładając go na Policję, jednostki pomocy społecznej (m.in. na pracownika socjalnego, gminne komisje rozwiązywania problemów alkoholowych, instytucje oświaty — pedagog, nauczyciel, psycholog szkolny), instytucje ochrony zdrowia (m.in. pielęgniarka, lekarz, ratownik) ${ }^{24}$. Istotnym elementem systemu ochrony ofiar przemocy $\mathrm{w}$ rodzinie było wprowadzenie do kodeksu postępowania karnego artykułu 244§1a i 1b, tj. zatrzymanie przez Policję osoby podejrzanej o popełnienie przestępstwa z użyciem przemocy wobec osoby wspólnie zamieszkującej, oraz artykułu 275a, na którego podstawie można wobec sprawcy przemocy zastosować środek zapobiegawczy polegający na nakazaniu mu opuszczenia lokalu, jeśli zamieszkuje go z ofiarą.

Na samorządy szczebla wojewódzkiego, powiatowego i gminnego nałożono obowiązek tworzenia programów przeciwdziałania przemocy w rodzinie. Powiaty i gminy mają za zadanie świadczenie pomocy specjalistycznej dla osób doświadczających przemocy, tworzenie programów oddziaływań korekcyjno-

22 Sprawozdania z realizacji Krajowego Programu Przeciwdziałania Przemocy w Rodzinie dostępne są na stronie internetowej Ministerstwa Rodziny, Pracy i Polityki Społecznej, https://www.gov.pl/web/rodzina/sprawozdania-z-realizacji-krajowego-programu-przeciw dzialania-przemocy-w-rodzinie. Wdrażaniem programu w skali kraju i województwa zajmują się odpowiednio Krajowy i Wojewódzki Koordynator Realizacji Krajowego Programu Przeciwdziałania Przemocy w Rodzinie.

${ }^{23}$ Zadaniem grup roboczych jest opracowanie i realizacja planu pomocy w indywidualnych przypadkach wystąpienia przemocy w rodzinie, monitorowanie sytuacji rodzin, w których dochodzi do przemocy, oraz rodzin zagrożonych wystąpieniem przemocy, dokumentowanie działań podejmowanych wobec rodzin, w których dochodzi do przemocy, oraz efektów tych działań. Skład grupy roboczej jest dostosowywany do charakteru i skali problemu.

${ }^{24} \mathrm{~W}$ skład grupy roboczej powołać można pracownika socjalnego, dzielnicowego, jeżeli w rodzinie są dzieci w wieku szkolnym — pedagoga szkolnego, a także psychologów bądź terapeutów pracujących z osobami doznającymi przemocy lub stosującymi przemoc, a jeśli zachodzi potrzeba - pracownika ochrony zdrowia, kuratora sądowego, asystenta rodziny lub innych specjalistów. 
-edukacyjnych dla osób stosujących przemoc w rodzinie, ochronę ofiar przemocy oraz tworzenie systemu wsparcia i pomocy, a także integrowania współpracy poszczególnych interesariuszy ${ }^{25}$. W ramach tych działań wójt/burmistrz/ prezydent miasta powołuje zespoły interdyscyplinarne, którym ustawodawca określił strukturę oraz zadania. W skład każdego zespołu interdyscyplinarnego mogą wchodzić przedstawiciele: Policji, pomocy społecznej, oświaty, ochrony zdrowia, gminnej komisji rozwiązywania problemów alkoholowych, kuratorzy sądowi oraz przedstawiciele organizacji pozarządowych. Dodatkowo do zespołu mogą być powołani prokuratorzy oraz przedstawiciele innych podmiotów działających na rzecz przeciwdziałania przemocy w rodzinie, w zależności od potrzeb pomocowych konkretnej rodziny (Gierszewski, 2019, s. 185) ${ }^{26}$.

Wraz z procesem tworzenia polityki przeciwdziałania przemocy w rodzinie w Polsce ukształtował się cały system interdyscyplinarnego działania wielu aktorów i uczestników polityki publicznej dotyczącej tego obszaru. Jak to już wskazano, realizacja zadań dotyczących przeciwdziałania przemocy w rodzinie stanowi jedno z podstawowych ustawowych obowiązków administracji rządowej oraz jednostek samorządu terytorialnego. Zgodnie z obowiązującą w Polsce dychotomiczną budową administracji publicznej zadania dotyczące przeciwdziałania przemocy wewnątrz rodziny wykonywane są w części przez administrację rządową - centralną i terenową, zespoloną $\mathrm{z}$ wojewodą i niezespoloną $\mathrm{z}$ wojewodą, oraz w wymiarze lokalnym lub regionalnym, przez jednostki samorządu terytorialnego, tj. gminę, powiat i samorząd województwa. Jednostki samorządu terytorialnego wykonują zadania za pośrednictwem swoich organów, jakimi są odpowiednio, jako organy stanowiące i kontrolne — rady gminy, powiatu lub sejmiku województwa oraz organów wykonawczych (Spurek, 2012, s. 99).

Zadania, które zostały określone $\mathrm{w}$ art. 6. UPPR, dotyczące przeciwdziałania przemocy w rodzinie, podzielić można na zadania własne jednostek samorządu terytorialnego oraz zadania zlecone z zakresu administracji rządowej, realizowane odpowiednio na poziomie gminy, powiatu i samorządu wojewódzkiego.

${ }^{25}$ Zadania związane $\mathrm{z}$ implementacją polityki przeciwdziałania przemocy w rodzinie przypisane są lokalnym jednostkom samorządu terytorialnego. To administracja najbliższa człowiekowi dostarcza mu świadczeń, wspiera go i chroni. W tym znaczeniu funkcja świadcząca nie jest realizowana ani przez administrację wojewódzką, ani centralną. Na szczeblu centralnym podstawową funkcję systemu pełni Krajowy Koordynator Realizacji Krajowego Programu Przeciwdziałania Przemocy w Rodzinie, Zespół Monitorujący ds. Przeciwdziałania Przemocy w Rodzinie działający przy Ministrze ds. Zabezpieczenia Społecznego oraz wojewódzcy koordynatorzy, którymi są osoby z wydziałów polityki społecznej urzędów wojewódzkich.

${ }^{26}$ Warto dodać, że jedyną gminą w Polsce, która nie zrealizowała obowiązku uchwalenia programu przeciwdziałania przemocy w rodzinie oraz $\mathrm{w}$ której nie powołano zespo$\mathrm{\jmath u}$ interdyscyplinarnego, jest Zakopane. Zob. https://serwisy.gazetaprawna.pl/samorzad/ artykuly/875256,zakopane-bez-kary-za-brak-programu-walki-z-przemoca-domowa.html (data dostępu: 21.02.2020). 
Realizacja przeciwdziałania przemocy w rodzinie, na poziomie centralnym oraz samorządowym, dokonywana jest w praktyce poprzez wykonywanie ustawy o pomocy społecznej oraz ustawy o wychowaniu w trzeźwości i przeciwdziałaniu alkoholizmowi, które to wprost odnoszą się w swoich przepisach do przemocy w rodzinie (Kiełtyka, Ważny, 2015, s. 105).

Działania UPPR są realizowane na kilku poziomach społecznych. Ustawa w swoich przepisach określa zadania podmiotów centralnych — odpowiednich ministrów - między innymi ministra właściwego do spraw zabezpieczenia społecznego (Ustawa z dnia 29 lipca 2005 r., art. 8), ministrów właściwych do spraw zdrowia, spraw wewnętrznych i administracji (Ustawa z dnia 29 lipca 2005 r., art. 12a.6), wojewódzkich - wojewodów i samorządów województw, powiatów oraz gmin ${ }^{27}$. Obowiązek realizacji zadań z zakresu przemocy w rodzinie spoczywa także na instytucjach publicznych, organizacjach i stowarzyszeniach. Wśród wielu przywołać można podmioty sytemu oświaty ${ }^{28}$, Rzecznika Praw Dziecka ${ }^{29}$, Komitet Ochrony Praw Dziecka ${ }^{30}$, Ogólnopolskie Pogotowie dla Ofiar Przemocy w Rodzinie „Niebieska Linia” ${ }^{31}$ i inne.

27 Art. 6 UPPR zakłada, że zadania te realizowane są na zasadach określonych w przepisach Ustawy z dnia 12 marca 2004r. o pomocy społecznej (Dz.U. z 2015 r. poz. 163, z późn. zm.) lub Ustawy z dnia 26 października 1982 r. o wychowaniu w trzeźwości i przeciwdziałaniu alkoholizmowi (Dz.U. z 2015 r. poz. 1286), chyba że przepisy ustawy stanowią inaczej. Przeciwdziałanie przemocy w rodzinie powinno zajmować priorytetowe miejsce wśród zadań realizowanych przez organy państwa, instytucje i organizacji.

${ }^{28} \mathrm{~W}$ dniu 1 sierpnia 2010 r. do obrotu prawnego weszła znowelizowana Ustawa o przeciwdziałaniu przemocy w rodzinie, która następnie uzupełniona przepisami wykonawczymi rozporządzenia Rady Ministrów, z dnia 13 września 2011 r., w sprawie procedury „Niebieskie Karty”, a także rozporządzenia Ministra Edukacji Narodowej w sprawie zasad udzielania i organizacji pomocy psychologiczno-pedagogicznej w publicznych przedszkolach, szkołach i placówkach, poszerzyła zakres działań placówek oświatowych w kwestii przeciwdziałania przemocy w rodzinie.

29 Rzecznik Praw Dziecka stoi na straży praw dziecka określonych w Konstytucji Rzeczypospolitej Polskiej, Konwencji o Prawach Dziecka i innych przepisach prawa. W zakresie przeciwdziałania przemocy domowej wobec dziecka Rzecznik Praw Dziecka może kierować do podmiotów oficjalne wystąpienia (generalne) w sprawach dotyczących przemocy w rodzinie $\mathrm{z}$ poszanowaniem odpowiedzialności, praw i obowiązków rodziców.

${ }^{30}$ Komitet Ochrony Praw Dziecka to ogólnopolskie stowarzyszenie, którego celem jest ochrona dziecka przed krzywdą i naruszaniem jego podstawowych praw i interesów. Zostało ono powołane w 1981 r. z inicjatywy Marii Łopatkowej. Prowadzi działalność interwencyjno-mediacyjną oraz edukacyjną w zakresie upowszechniania znajomości praw dziecka.

31 Ogólnopolskie Pogotowie dla Ofiar Przemocy w Rodzinie „Niebieska Linia” powstało w 1995 r. jako placówka Instytutu Psychologii Zdrowia Polskiego Towarzystwa Psychologicznego i realizuje zadania $\mathrm{w}$ zakresie przeciwdziałania przemocy $\mathrm{w}$ rodzinie na zlecenie wielu instytucji państwowych i samorządowych oraz zagranicznych. 


\section{Podsumowanie}

Ocena rezultatów tworzenia i wdrażania polityki przeciwdziałania przemocy w rodzinie w Polsce nie jest rzeczą łatwą. Na taki stan składa się wiele elementów, wśród których wymienić można wielodyscyplinarność podejścia do problematyki przemocy domowej, co z kolei determinuje sam sposób definiowania problemu i zastosowanie określonych narzędzi badania i oceny podejmowanych działań. Skuteczny system pomocy ofiarom przestępstw i zapobiegania przemocy w relacjach rodzinnych zależy w dużej mierze od synergii w działaniu podmiotów różnych szczebli władzy i łączeniu zasobów wielu interesariuszy problemu. Nie bez znaczenia jest stopień społecznego rozumienia problemu i akceptacji dla określonych działań na poziomie politycznym. Zarysowany w artykule proces kształtowania się światowych i wewnętrznych mechanizmów sprzyjających wprowadzeniu przemocy w rodzinie do agendy problemów społecznych, a także kolejne inicjatywy i działania podejmowane na gruncie krajowym sprawiają, że w Polsce od lat osiemdziesiątych XX wieku nastąpiło ujawnienie problemu społecznego, jakim jest przemoc w rodzinie, podjęto też próbę tworzenia (mniej lub bardziej świadomie z punktu widzenia administracji państwowej) systemu przeciwdziałania przemocy w rodzinie w kontekście tworzenia instytucji, stanowienia prawa oraz konsolidacji działań interesariuszy ${ }^{32}$.

Wydaje się, że istniejąca polityka publiczna przeciwdziałania przemocy w rodzinie w Polsce, w zakresie projektowania i implementacji, odbiega od idei polityki publicznej, szczególnie w pierwszej fazie identyfikacji problemu przemocy w rodzinie w latach przed rokiem 2005. Wydaje się, że formułowanie problemu, jego identyfikacja oraz implementacja były wypadkową różnych działań podejmowanych przez organizacje obrońców praw człowieka (dziecka) i ruchy feministyczne, autorów raportów i sugestie specjalistów zajmujących się rozwiązywaniem problemów alkoholowych, wyników badań i analiz środowisk akademickich, z dostosowaniem prawa do standardów i zobowiązań międzynarodowych włącznie. Brak jest też komplementarnych, powtarzalnych projektów badawczych w zakresie badania i analizy zjawiska przemocy w rodzinie, konsekwencji społecznych, zdrowotnych i w końcu kosztów dla budżetu państwa ${ }^{33}$,

32 Wprowadzono regulacje prawne, które obejmują zmiany ustrojowe w zakresie administracji państwowej i samorządowej, prawa i polityki karnej, ochrony zdrowia, edukacji, pomocy społecznej, ochrony rodziny i opieki nad dzieckiem. Uregulowano zakres i warunki działania organizacji pozarządowych.

${ }^{33}$ Raport „Ocena efektywności systemu przeciwdziałania przemocy przez profesjonalistów”. Badanie to stanowi część ogólnopolskiego badania pn. „Diagnoza i porównanie skali zjawiska przemocy w rodzinie oraz ocena efektywności działań podejmowanych na rzecz przeciwdziałania przemocy w rodzinie”, realizowanego w ramach Projektu pn. „Rodzina polska - wolna od przemocy” dla Programu Operacyjnego PL 14 „Przeciwdziałanie prze- 
a także konsensu politycznego co do niektórych rozwiązań ${ }^{34}$. Mimo podnoszonych zastrzeżeń zauważyć trzeba, że stworzona i realizowana jest w Polsce polityka przeciwdziałania przemocy w rodzinie. Polityka ta oparta jest na wielu filarach (legislacja, administracja, organizacje pozarządowe), które pozwalają na jej wszechstronną ewaluację i projektowanie w zależności od zmieniających się okoliczności, możliwości i potrzeb ofiar przemocy w rodzinie.

\section{Bibliografia}

„10 lat ustawy o przeciwdziałaniu przemocy $w$ rodzinie - historia, doświadczenia, wyzwania”. Jachranka 14-15 grudnia 2015. Materiały z ogólnopolskiej konferencji. Pobrano z: https://www.prawo.pl/kadry/10-lat-ustawy-o-przeciwdzialaniu-przemocy-w-rodzi nie, 284110.html (data dostępu: 2.01.2020).

Anioł, W., (2018). Wielonurtowy i interdyscyplinarny charakter nauk o polityce publicznej. W: B. Szatur-Janowska, (red.), Polityki publiczne. Wybrane zagadnienia teoretyczne i metodologiczne (s. 19-52). Warszawa: Wydawnictwo Uniwersytetu Warszawskiego.

Archiwum MS, (2018). Pobrano z: https://www.arch.ms.gov.pl/pl/dzialalnosc/przeciwdzialanieprzemocy-domowej/ogolne/akty-prawne-i-inne-dokumenty-/ (data dostępu: 2.01.2020).

Ard, K., Makadon, H. (2011). Addressing Intimate Partner Violence in Lesbian, Gay, Bisexual, and Transgender Patients. Journal of General Internal Medicine, vol. 26 (8), s. 930933

Becker, H.S. (ed.). (1966). Social Problems. A Modern Approach. New York: John Wiley $\&$ Sons.

Bednarzak, J. (1974). Ustawa z dnia 18 lipca 1974 r. o amnestii. Warszawa: Wydawnictwo Prawnicze.

Bezpieczeństwo $w$ rodzinie, 2014. Pobrano z: https://www.parpa.pl/index.php/ przeciwdzialanie-przemocy/bezpieczenstwo-w- rodzinie (data dostępu: 12.01.2020).

Bińczyk-Missala, A., (2008). Międzynarodowa ochrona praw człowieka. Warszawa: Wydawnictwo Uniwersytetu Warszawskiego.

Bołdyrew, A. (2009). Kara i strach w wychowaniu dzieci w polskich rodzinach w XIX w. Dziecko Krzywdzone, vol. 8, no. 3.

Browne, K.D., Dixon, L., (2003). Związki między przemoca matżeńska i krzywdzeniem dzieci, a terapia sprawców przemocy domowej. Pobrano z: www.dzieckokrzywdzone.pl (data dostępu: 2.01.2010).

Bryk, J., (2003). Przestepstwo znęcania się. Studium prawnokarne i kryminologiczne. Szczytno: Wydawnictwo Wyższej Szkoły Policji.

mocy w rodzinie i przemocy ze względu na płeć", współfinansowanego ze środków Norweskiego Mechanizmu Finansowego (NMF) na lata 2009-2014. Realizatorem badania była firma WYG PSDB sp. z o.o. na zlecenie Ministerstwa Pracy i Polityki Społecznej.

${ }^{34}$ Patrz kontrowersje w sprawie ratyfikacji Konwencji Rady Europy o zapobieganiu i przeciwdziałaniu przemocy wobec kobiet i przemocy domowej. Wywołana tym wydarzeniem debata publiczna ujawniła liczne obawy co do zasadności ratyfikowania Konwencji przez Polskę (obawy o wypaczenie pojęcia rodziny, roli religii i tradycji). 
Castiglia, P.T., (1995). Family Violence. Journal of Pediatric Health Care, vol. 9, no. 6, s. 269-271. DOI: https://doi.org/10.1016/S0891-5245(05)80062-8.

Chan, K.O., Choi, A., Wai, M., Fong, D.Y.T., Chow, C.B., Leung, M., Ip, I., (2013). Characteristics of Family Violence Victims Presenting to Emergency Departments in Hong Kong. Journal of Emergency Medicine, vol. 44, no. 1, s. 249-258. DOI: https://doi. org/10.1016/j.jemermed.2012.01.061.

Dominiczak, A. (red.). (2000). Przemoc w rodzinie wobec kobiet i dzieci. Warszawa: Fundacja Centrum Praw Kobiet.

Emery, R., (1989). Family Violence. American Psychologist, vol. 44, no. 2, s. 321-328. DOI: https://doi.org/10.1037/0003-066X.44.2.321.

Gapiński, B. (2008). Sacrum i codzienność. Prośby o modlitwę nadsyłane do Kalwarii Zebrzydowskiej w latach 1965-1979. Warszawa: Wydawnictwo Trio.

George M.J. (1994). Riding the Donkey Backwards: Men as the Unacceptable Victims of Martial Violence. Journal of Men's Studies No. 3 (2), s. 137-159.

Gierszewski, J., (2019). Policja w systemie zapobiegania przemocy w rodzinie. Studia Politologiczne, T. 51, s. 174-196. DOI: https://doi.org/10.33896/SPol.2019.51.10.

Golinowska, S., (1994). Polityka społeczna w gospodarce rynkowej. Studium ekonomiczne, Warszawa: PWN.

Hague, G., Malos, E., (1994). Domestic Violence Action for Change. Bristol: University of Bristol.

Haj-Yahia, Z.M., de Zoysa, P., (2008). Rates and Psychological Effects of Exposure to Family Violence among Sri Lankan University Students. Child Abuse \& Neglect, vol. 32, no. 10, s. 994-1002. DOI: https://doi.org/10.1016/j.chiabu.2008.05.001.

https://serwisy.gazetaprawna.pl/samorzad/artykuly/875256,zakopane-bez-kary-za-brak-pro gramu-walki-z-przemoca-domowa.html (data dostępu: 21.02.2020).

https://www.gov.pl/web/rodzina/sprawozdania-z-realizacji-krajowego-programu-przeciwdzialania-przemocy-w-rodzinie (data dostępu: 21.02.2020).

Jarosz, E., (1999). Przemoc wewnątrzrodzinna. W: D. Lalak, T. Pilch, (red.), Elementarne pojęcia pedagogiki społecznej i pracy socjalnej, (s. 220-221). Warszawa: Wydawnictwo Akademickie „Żak”.

Jarosz, E., (2009), Ochrona dzieci przed krzywdzeniem. Perspektywa lokalna i globalna, Katowice: Wydawnictwo Uniwersytetu Śląskiego.

Jaszczak-Kuźmińska, D., Michalska, K., (red.). (2010). Przemoc w rodzinie wobec osób starszych i niepetnosprawnych. Poradnik dla pracowników pierwszego kontaktu. Warszawa: Ministerstwo Pracy i Polityki Społecznej.

Jelonek, M., Keler, K., Worek, B., (2010). Dane — ich gromadzenie, integracja i jakość. W: J. Górniak, S. Mazur, (red.), W kierunku polityki rynku pracy opartej na dowodach, s. 35-83. Warszawa: Obserwatorium Regionalnych Rynków Pracy Pracodawców Rzeczypospolitej Polskiej.

Kaczmarek, T. (red.). (1979). Przestępczość przeciwko rodzinie, opiece i młodzieży. Materiaty VI Wrocławskiego Sympozjum Kryminologicznego 18-19 październik 1979. Wrocław: Wydawnictwa Uniwersytetu Wrocławskiego.

Karta Narodów Zjednoczonych. Dz.U. z 1947, nr. 23, poz. 90.

Kempe, C.H., Silverman, F.N., Steele, B.F., Droegemuller, W., Silver, H.K., (2005), Zespół dziecka maltretowanego. Dziecko Krzywdzone. Teoria, badania, praktyka, vol. 4, no. 2, s. $11-20$.

Kiełtyka A., Ważny A., (2015). Przeciwdziałanie przemocy w rodzinie. Komentarz. Warszawa: Wolters Kluwer.

Klich-Kluczewska, B. (2014). „W tym domu panuje strach”. Kultura przemocy i porządek płci w Polsce późnego komunizmu. Rocznik Antropologii Historii, R. 4, nr 2(7), s. 165-179. 
Klich-Kluczewska, B., (2015). Rodzina, tabu i komunizm w Polsce 1956-1989. Kraków: Wydawnictwo „Libron”.

Kosiński, K. (2002). Nastolatki 81. Świadomość młodzieży w epoce „Solidarności”. Warszawa: Wydawnictwo Trio.

Kosiński, K., (2006). Oficjalne i prywatne życie młodzieży w czasach PRL. Warszawa: Rosner \& Wspólnicy.

Kosiński, K., (2008). Historia pijaństwa w czasach PRL. Warszawa: Neriton.

Kozłowska, D., (2015). Procedura „Niebieskie Karty”. Geneza i rozwój. Kwartalnik Policyjny $n r 3$ (34), s. 4-14.

Krupka-Matuszczyk, I., (red.). (2004). Wybrane zagadnienia z psychologii klinicznej. Podręcznik dla studentów medycyny i lekarzy. Katowice: Wydawnictwo Śląskiego Uniwersytetu Medycznego.

Kudlińska, I., (2014). Socjologia a praktyka rozwiązywania problemów społecznych między naukowymi a nieformalnymi teoriami problemów społecznych. Acta Universitatis Lodziensis, Folia Sociologica, T. 50, s. 137-151.

Kwaśniewski, J., (1984). Society and Deviance in Communist Poland. Attitudes Towards Social Control. Lemington Spa: Berg.

Kwietniewska, M., (2013). Polityka publiczna dotycząca przemocy domowe wobec kobiet w Unii Europejskiej. Policja, $n r$ 2, s. 21-27.

Lamela, D., Iongenelen, I., Levendovsky, A., (2018). Typologies of Intimate Partner Violence-maternal Parenting and Children's Externalizing Problems: The Moderating Effect of the Exposure to Other Forms of Family Violence. Child Abuse \& Neglect, vol. 81, s. 60-73. DOI: https://doi.org/10.1016/j.chiabu.2018.04.020.

Lelek-Kratiuk, M., (2014). Przemoc domowa wobec kobiet - weryfikacja mitów i ustalanie prawdy. Państwo i Społeczeństwo, nr 2, s. 79-99.

Marciński, A., (2005). Dziecko maltretowane - urazy nieprzypadkowe. Dziecko Krzywdzone. Teoria, badania, praktyka, vol. 4, no. 2, s. 30-42.

Mazur, S., (2015). Założenia teoretyczne i metodologiczne nauk o polityce publicznej. Wroctawskie Studia Politologiczne, nr 18, s. 7-27.

Mellibruda, J., Organizacje $i$ instytucje pomagajace ofiarom przemocy $w$ rodzinie (stan na sierpień 2006). Raport ogólnopolski (za okres styczeń-sierpień 2006) z realizacji projektu Niebieska Sieć. Sieć liderów lokalnych organizacji na rzecz przeciwdziałania przemocy w rodzinie. Instytut Psychologii Zdrowia PTP. Pobrano z: www.niebieskalinia.pl/ spaw/docs/raport2006.pdf (data dostępu: 2.01.2020).

Mering, T. (2018). Implementacja polityk publicznych: aspekty metodologiczne i teoretyczne. W: B. Szatur-Jaworska, (red.), Polityki publiczne. Wybrane zagadnienia teoretyczne $i$ metodologiczne. Warszawa: Wydawnictwo Uniwersytetu Warszawskiego, s. 159-184.

Niebieska linia. Pobrano z: https://www.niebieskalinia.pl/pismo/wydania/dostepne-artykuly/ 4463-w-drodze (data dostępu: 12.01.2020).

Peyrefitt, A. (red.). (1982). Społeczeństwo wobec przemocy. Raport Komitetu Badań Nad Przemoca, Zbrodnia i Wystepkiem. (red. wydania polskiego B. Hołyst). Warszawa: PWN.

Portret kobiety: Hanna Lipowska-Teutsch, 2001. Pobrano z: https://www.wysokieobcasy.pl/ wysokie-obcasy/1,53662,219512.html (data dostępu: 2.01.2020).

Pospiszyl, I., (1994). Przemoc w rodzinie. Warszawa: Wydawnictwa Szkolne i Pedagogiczne, Pospiszyl, I., (2008). Patologie społeczne. Warszawa: Wydawnictwo Naukowe PWN,

Program „Przeciw przemocy - wyrównać szanse”, 1998. Pobrano z: http://www.srk.opoka. org.pl/srk/srk_pliki/dokumenty/prprzpr.html (data dostępu: 15.01.2020).

Przeciwdziałanie przemocy w rodzinie przez administracje publiczna (2013). Warszawa: Najwyższa Izba Kontroli. 
Rymsza, M. (2016). Polityka rodzinna: cele, wartości, rozwiązania — w poszukiwaniu konsensualnego programu. Studia BAS, $n r 1$ (45).

Rymsza, M. (2015). Polityka społeczna wobec kwestii społecznej w XXI wieku. W: E. Giermanowska, M. Racław, M. Rymsza, (red.), Kwestia społeczna u progu XXI wieku. Księga jubileuszowa dla profesor Józefiny Hrynkiewicz (s. 27-41). Warszawa: Wydawnictwa Uniwersytetu Warszawskiego.

Sakowicz, M., (2016). Analiza polityki publicznej z wykorzystaniem modelu cyklu działań publicznych jako narzędzia podnoszenia jakości działań we współczesnym państwie. W: J. Osiński, I. Zawiślańska, (red.), Polityka publiczna. Teoria, jakość, dobre praktyki. Warszawa: Oficyna Wydawnicza SGH. Szkoła Główna Handlowa.

Sasal, H.D., (2001). Ludzie pomagają ludziom. Niebieskie karty po dwóch latach. Niebieska Linia, $n r 2 / 13$.

Słowiński, K., (2013). Wybrane problemy życia codziennego Polaków na podstawie listów opublikowanych na łamach „Przyjaciółki” w latach 1956-1970. Pamięć i Sprawiedliwość, $n r$ 12/1 (21).

Spurek, S., (2012). Przeciwdziałanie przemocy w rodzinie. Komentarz. Warszawa: Wolters Kluwer.

Stoba, Cz., Sroka, M., (2002). Historyczne i etyczne aspekty przemocy nad dzieckiem. Psychiatria w Praktyce Ogólnolekarskiej, $n r$ 4, s. 245-249.

Straus, M.A., Ramirez I.L. (2007). Gender Symmetry in Prevalence, Severity, and Chronicityof Physical Aggression Against Dating Partners by University Students in Mexico and USA. Aggressive Behavior vol. 33, s. 281-290.

Szymańczak, J., (2000). Przemoc w rodzinie. Zarys problematyki. Raport nr 181. Warszawa: Kancelaria Sejmu Biuro Studiów i Ekspertyz.

Theiss, W., (1995). Trudności i zagrożenia w funkcjonowaniu środowisk wychowawczych współczesnej Polski. W: K. Franczak, J. Niewęgłowski, (red.), Wychowanie wobec zachodzacych przemian (s. 5-16). Warszawa: Salezjański Instytut Wychowania Chrześcijańskiego: Fundacja „Młodzież w Potrzebie”.

Tkaczyński, J.W., Świstak, M., (2015). Polityki publiczne - zagadnienia teoretyczne. W: M. Świstak, J.W. Tkaczyński, (red.), Wybrane polityki publiczne Unii Europejskiej. Stan i perspektywy. Kraków: Wydawnictwo Uniwersytetu Jagiellońskiego.

Tobis, A. (1980). Główne przestęstwa przeciwko rodzinie. Charakterystyka prawna i skuteczność kary pozbawienia wolności. Poznań: Wydawnictwo Naukowe UAM.

Topolewska, M. (2015). Zakopane bez kary za brak programu walki z przemoca domowa. Pobrano z: https://serwisy.gazetaprawna.pl/samorzad/artykuly/875256,zakopane-bez-karyza-brak-programu-walki-z-przemoca-domowa.html (data dostępu: 2.01.2020).

Ustawa z 10 czerwca 2010 r., o zmianie ustawy o przeciwdziałaniu przemocy w rodzinie oraz niektórych innych ustaw. (Dz.U. nr 125 poz. 842).

Ustawa z dnia 29 lipca 2005 roku o przeciwdziałaniu przemocy w rodzinie. (Dz.U. nr 180 poz. 1493 ze zm.).

Walby, S., Allen, J., Domestic Violence, Sexual Assault and Stalking: Findings from the British Crime Survey, „Home Office Research Study” 276, London 2004. Pobrano z: www. avaproject.org.uk/media/28384/hors276.pdf (data dostępu: 2.01.2020).

Walby, S., The Cost of Domestic Violence, Women and Equality Unit 2004. Pobrano z: www. devon.gov.uk/cost_of_dv_report_sept04.pdf (data dostępu: 2.01.2020).

Walby, S., The Cost of Domestic Violence: Update 2009, „UNESCO Chair in Gender Research", Lancaster University, UK 2009. Pobrano z: www.lancs.ac.uk/fass/sociology/profiles/34/ (data dostępu: 2.01.2020).

Walker, L.E.A., (2002). Politics, Psychology and the Battered Woman's Movement. Journal of Trauma Practice, no. 1 (1), s. 81-102. DOI: https://doi.org/10.1300/J189v01n01_05. 
Wiślicz, T. (2012). Upodobanie: Matzeństwo i zwiazki nieformalne na wsi polskiej XVIIXVIII wieku. Wrocław: Chronicon.

Włodarczyk, J., (2014). Rola backlashu w instytucjonalizacji problemu wykorzystywania seksualnego dzieci. Analiza przypadku Stanów Zjednoczonych pod koniec XX wieku. Dziecko Krzywdzone. Teoria, Badania, Praktyka, nr 13 (1).

Woźnicki, J., (2012). Nowa dyscyplina — „,nauki o polityce publicznej” usytuowana w dziedzinie nauk społecznych. Nauka, $n r 1$.

Zalewski, P., Janułajtys, D., (2017). Zjawisko przemocy w rodzinie w Polsce z perspektywy 20 lat realizacji procedury „Niebieskie Karty”. W: M. Świtała-Cheda, J. Cheda, (red.), Człowiek we współczesnym świecie. Zagadnienia wybrane. Krosno-Rozworzyn: Wydawnictwo „Mentoris”.

Zielińska, A., (1993). Przemoc wobec dziecka jako przykład zaburzenia relacji międzyludzkich w rodzinie. W: A. Przecławska (red.), Relacje między ludźmi jako przedmiot badań pedagogicznych. Warszawa: Oficyna Edytorska „Civitas”.

Ziemierski, M. (2010). Przemoc domowa w Krakowie w latach 1650-1763 w świetle mieszczańskich testamentów i inwentarzy. Rocznik Biblioteki Naukowej PAU I PAN W Krakowie, R. 15.

Zybała, A., (2012). Polityki publiczne. Doświadczenia w tworzeniu i wykonywaniu programów publicznych $w$ Polsce $i$ w innych krajach. Warszawa: Krajowa Szkoła Administracji Publicznej.

Zybała, A., (2013). Państwo i spoteczeństwo w działaniu. Polityki publiczne wobec potrzeb modernizacji państwa i spoleczeństwa. Warszawa: Difin.

Zybała, A., (2014). Architektura polityki walki z przemocą w rodzinie. Polityka Społeczna, nr 7. Pobrano z: http://kolegia.sgh.waw.pl/pl/KES/struktura/kppb/katedra/sklad/Docu ments/Polityka\%20walki\%20z\%20przemoca\%207_2014.pdf (data dostępu: 26.12.2019).

Piotr Zalewski, dr, podinspektor Policji, Wydział Prawa i Nauk Społecznych Uniwersytetu Jana Kochanowskiego w Kielcach, Komendant Miejski Policji w Kielcach. Zajmuje się problematyką zarządzania bezpieczeństwem, bezpieczeństwem wewnętrznym, strategiami bezpieczeństwa, teorią konfliktów oraz patologiami społecznymi. 